\title{
The Determinants of eWoM in Social Commerce:
}

\section{The Role of Perceived Value, Perceived Enjoyment, Trust, Risks, and Satisfaction}

\author{
Kamel Rouibah, Kuwait University, Kuwait \\ (iD) https://orcid.org/0000-0003-3652-5610 \\ Nabeel Al-Qirim, College of IT, United Arab Emirates University, UAE \\ (iD) https://orcid.org/0000-0002-0090-7521 \\ Yujong Hwang, DePaul University, USA \& Kyung Hee University, South Korea \\ Sara Ghasem Pouri, College of Business Administration, Kuwait University, Kuwait
}

\begin{abstract}
The influence of eWoM use for s-commerce in the context of Arab region remains unexplored. To bridge this gap, this study develops a model for eWoM use for s-commerce post adoption. This model link three antecedents-factors (trust towards other people, trust of internet/Instagram, and perceived risks) to eWoM use for s-commerce through the mediation of perceived enjoyment, perceived value, and customer satisfaction. The model is validated with a large sample of 843 Instagram users using LISREL tool. Research findings revealed that propensity to trust, trust of internet, perceived risk, and perceived value affect use of eWoM through the indirect effect of perceived enjoyment and satisfaction, while perceived value has no direct effect on eWoM. Customer satisfaction was a predominant predictor of eWoM use. The model has relevant contributions and implications for both research and practice.
\end{abstract}

\section{KEYWORDS}

eWoM, Perceived Enjoyment, Perceived Risk, Propensity To trust, Social Commerce, Trust of Internet

\section{INTRODUCTION}

\section{From Social Network Tools to Social Commerce}

While Online Social Network -OSN- tools adoption in socialization have received an extensive coverage in the literature (Chu \& Sung, 2015; Olanrewaju et al., 2020), still their usage for social commerce (noted here as s-commerce) purpose in developing countries, especially in an Arab context is questionable and have received lesser attention from researchers despite its increasing rate (Shin, 2013; Mikalef et al., 2017; Mikalef et al., 2013; Cheng et al., 2019; Molinillo et al., 2020). Hence, more theoretical development is needed to describe the specific characteristic of s-commerce and the factors influencing consumers' current adoption of s-commerce.

S-commerce is defined as the exchange-related activities that can be influenced by an individual's Online Social Network (OSN) in computer-mediated social environments - where the activities correspond to need recognition, pre-purchase, purchase, and post-purchase stages. Taking advantage

\section{DOI: 10.4018/JGIM.2021050104}

This article, published as an Open Access article on April 16, 2021 in the gold Open Access journal, Journal of Global Information Management (JGIM) (converted to gold Open Access on January 1, 2021), is distributed under the terms of the Creative Commons Attribution 
of user generated content and electronic word of mouth (eWoM), social interaction encourages sales and transactions by connecting people who have similar opinions but have no initial prior connection. S-commerce can come in three types: (i) using e-commerce website to build community (e.g. Airbnb), (ii) combining OSN tools and e-commerce activities (e.g. Instagram), and (ii) bring a third-party s-commerce platform (e.g. TripAdvisor). This classification includes the five categories proposed by Cheung \& Thadani (2012): Online discussion forums, online consumer review sites, blogs, OSN tools, and online brand/ shopping. Regarding the mentioned types, this study focuses on OSN which is the fastest-growing driver of e-commerce referrals. It is driven by 3.5 billion social media users and 5.1 billion mobile users in 2019; $52 \%$ of marketers believe that s-commerce is one of the most important investment areas (Greenlight, 2020) and 87\% of e-shoppers accepts that social media helps them in making shopping decision, and $40 \%$ of merchants use social media to generate sales (Global Digital Report, 2020). Moreover, it was observed that the adoption levels of s-commerce is limited despite that consumers are switching from e-commerce to s-commerce ( $\mathrm{Li} \& \mathrm{Ku}, 2018$ ), which gives a highlight about the importance of conducting more research (Salvatori \& Marcantoni, 2015; Akman \& Mishra, 2017; Shin, 2013; Mikalef et al., 2017; Abed, 2020; Cheng et al., 2019). In fact, s-commerce is still considered a novelty that is evolving. Indeed $36 \%$ of customers searching for information about products on OSN before purchasing, and the number of marketers who use them (e.g. Instagram) for business has grown from 53.2\% to 73.2\% over the last three years (Beaulac, 2020).

\section{Research Focus and Motivations}

This paper investigates the factors that influence individuals' behavioral toward eWoM current use. Our literature review covers the most extensive efforts that integrate utilitarian and hedonic value (Zhang et al., 2018; Shin, 2013; Mikalef et al., 2013; Pöyry et al., 2013; Shen, 2012), trust (Gibreel et al., 2018; Akman \& Mishra, 2017; Molinillo et al., 2020; Kim \& Park, 2013; Cheng et al., 2019; Qin \& Kong, 2015)and antecedent of eWoM (Mikalef et al., 2017; Mikalef et al., 2013; Qin \& Kong, 2015; Pöyry et al., 2013; Kim \& Park, 2013; Molinillo et al., 2020). Although these studies have provided a useful foundation for studying s-commerce, still there are five missed opportunities-which all of them are addressed in this paper-to provide unique contributions that build on the literature.

First, with regards to s-commerce typologies, majority of researches focused primarily on factors affecting s-commerce web sites (Molinillo et al., 2020; Mikalef et al., 2017; Wang \& Yu, 2017; Bugshan \& Attar, 2020; Shen, 2012; Kim \& Park, 2013), and fewer focused on OSN tools such as Facebook (Molinillo et al., 2020; Pöyry et al., 2013; Mikalef et al., 2013; Mikalef et al., 2017), and TripAdvisor (Coursaris et al., 2018) whereas other SNS as Instagram have been ignored. And to the best of our knowledge, there is no evidence of the impact of Instagram in the promotion of s-commerce.

Second, E-commerce (product-centered) and s-commerce (social-centered) are different since the later has its unique characteristics (Shen, 2012) and its proliferation is mainly based on eWoM (Lee, 2014; Cheng et al., 2019). While the influence of eWoM received considerable attention in consumer behavior and marketing, and information systems (Qin \& Kong, 2015; Molinillo et al., 2020; Mikalef et al., 2017; Mikalef et al., 2013; Pöyry et al., 2013; Kim \& Park, 2013) they focused also mainly on different factors that affect intention in using eWoM and ignoring the current behavior (i.e. current needs of customers to seek reviews to complete their actual purchasing). Conversely, there are IT studies that have found that intention does not necessarily lead to current behavior (Brusso, 2015; Tao, 2009). In addition, s-commerce based eWoM did not receive the due attention from Arab researchers.

Third, recent studies have recognized that s-commerce adoption is driven by utilitarian factors and hedonic value too, i.e. perceived enjoyment (Shen, 2012; Shin, 2013; Mikalef et al., 2013; Pöyry et al., 2013; Sharma \& Crossler, 2014; Gan \& Wang, 2017; Zhang et al., 2018). Still results of these studies are fragmented in their focus, ambiguous and do not clarify whether hedonic value impacts directly or indirectly intention to use/ eWoM. Furthermore, these studies are not conclusive about the relative importance of utilitarian value vs. hedonic value on intention to use eWoM. 
Fourth, prior s-commerce models integrate different transactional, information and social factors that impact intention to use or eWoM (Zhang et al., 2018; Bugshan \& Attar, 2020; Molinillo et al., 2020; Akman \& Mishra, 2017; Wang \& Yu, 2017; Mikalef et al., 2013; Pöyry et al., 2013). Nevertheless, they did not try to reconcile their model with well theory model, e.g. TAM (Davis et al., 1989). And there are relatively few attempts to justify the studied factors by combining the findings of quantitative and qualitative research.

Fifth, compare to trust effect, perceived risks received less attention (Farivar et al., 2017; Gan \& Wang, 2017). And prior studies have focused on trust either from the vendor (Kim \& Park, 2013; Hajli et al., 2017; Akman \& Mishra, 2017; Gibreel et al., 2018) or trust of technology /internet (Schaupp et al., 2010), but ignored to integrate trust of other people (Cheng et al., 2019; Farivar et al., 2017) and risk besides utilitarian and hedonic value. This is very important because users of OSN (e.g. Instagram) purchase products from other users without acquaintance and also make sales without a mediating agent or a return policy which increases risk perception (Gibreel et al., 2018). Likewise, referral systems are not used to reference products from search engines, and so the entire process is executed within the OSN tool itself from searching to purchasing products. Accordingly, trust is mediated by the community of the sellers and buyers themselves based on internet technology, and built within their daily communication and transactions.

Therefore, this study aims to fill the void in these five areas and expand on the trend of past studies by considering previously scattered factors (utilitarian value, hedonic value, trust, risk, satisfaction, eWoM current use) into an integrative model for s-commerce based Instagram and organize them to comply with, the marketing literature and TAM through the following research questions: which of these factors may be more critical for influencing different consumers' eWoM use in s-commerce context and in which a third party is no longer necessary to facilitate interaction between buyers and sellers?

This research attempts to extend surrogates to existing research in this area by developing and testing a new research model how eWoM is created in the absence of social clues. Our topic is consequential in both theories and practical importance as eWoM is often the primary communication channel for companies who may have shortage resources for traditional marketing especially for microbusiness, and eWoM has a direct effect on increased product sales/ revenue growth and customer retention, which in turn can generate further eWoM (Gauri et al., 2008; Yoo et al., 2013)

\section{LITERATURE REVIEW}

\section{Context of the Study: Instagram in an Arab Country}

This study focuses on Instagram adoption in Kuwait, a small Arab country among the six Gulf Cooperation Council- (GCC) countries. It has 17,820 square kilometers including 4.65 million habitants; having about $70 \%$ expatriates amid. Compared to other Arab countries, Kuwait ranks first in Internet penetration (Internet statistics, 2020) and first in Internet connection speed, and has a mobile phone penetration of 200\%, thus, making Kuwait among Arab leaders in Internet applications.

The social information processing theory (Salancik \& Pfeffer, 1978), and the information richness theory (Daft \& Lengel, 1986) gave justification concerning the reasons why Instagram is one important OSN for s-commerce. Firstly, both theories propose that individuals may be influenced by clues from others (here eWoM in s-commerce), and how others evaluate the same phenomena (Salancik \& Pfeffer, 1978). Different sources of information have different impacts on the outcomes. Social sources of information (people who post eWoM related to evaluations of products) are more likely to influence a users' attitude than non-social sources of information. As compared to face-to-face communication, the social information processing theory argues that online social communication based on eWoM achieves greater influence due to number of factors, including: the ability to influence a large number of individuals, minimal effort/cost to influence others. Secondly, according to information richness theory Instagram is considered a high communication tool that provides a list of functions that makes 
it very attractive for s-commerce: photo capturing and photo sharing tool, publish multimedia data in an easy way, availability of Likes to measure the efficiency of selling and provides feedback to both buyers and sellers. Thirdly, Instagram has more engagement rate with brands than any other OSN tool (Elliott, 2015). Fourthly, the six GCC countries have about 54 millions of internet users (Internet world stats, 2020), and $\$ 20$ billion of e-commerce (Statistica, 2020). Among the GCC countries, Kuwait has the highest penetration rate of Instagram (45\%) (Napoleoncat, 2020) especially among the young generation since 51\% are between the age 25-34 (Napoleoncat, 2020). Therefore, Kuwait resembles an ideal context for s-commerce adoption here.

\section{Factors Affecting S-Commerce Adoption}

A literature review about existing knowledge on s-commerce, e-commerce, and eWoM is presented in Appendix 1. Given the importance of s-commerce, our extensive review highlights the fundamental objectives.

Adoption is still an important challenge for companies, and researchers are calling for new theories especially in developing countries (Zhou et al., 2013; Salvatori \& Marcantoni, 2015; Baethge et al., 2016) and these models need to comply with TAM and marketing research.

In addition, existing s-commerce studies are most frequently contextualized in developed and English-speaking countries (cf., Shin, 2013; Akman \& Mishra, 2017; Mikalef et al., 2017; Cheng et al., 2019; Molinillo et al., 2020). Some of these studies conducted conceptual literature reviews (Zhou et al., 2013; Salvatori \& Marcantoni, 2015; Baethge et al., 2016; Zhang \& Benyoucef, 2016; Han et al., 2018), or developed theoretical models without any empirical validation (Cheung \& Thadani, 2012; Zhou et al., 2013; Hajli et al., 2014), while another category developed models for s-commerce adoption. The last stream revealed that different theories (see Appendix 1) were used to measure different outcomes (intention to search, intention to buy, intention stickiness, brand attitude, customer loyalty, social engagement, and eWoM, continuous use). In addition, different transactions, information and social factors were identified. These include trust in web sites and Apps (Cheng et al., 2019; Bugshan \& Attar, 2020), community trust (Molinillo et al., 2020; Cheng et al., 2019; Farivar et al., 2017), perceived trust (Shin, 2013; Akman \& Mishra, 2017; Gibreel et al., 2018), trust disposition (Cheng et al., 2019), utilitarian value / perceived usefulness (Shin, 2013; Hu et al., 2016; Abed, 2020; Gibreel et al., 2018), ease of use (Doha et al., 2019), social capital and engagement (Doha et al., 2019), social value (Hu et al., 2016), social influence and hedonic value/ perceived enjoyment (Shin, 2013; Akman \& Mishra, 2017), perceived awareness (Akman \& Mishra, 2017), satisfaction (Akman \& Mishra, 2017; Gan \& Wang, 2017), peer characteristics and technical features (Hu et al., 2016), socialization, personal recommendation agents, product selection, and information availability (Mikalef et al., 2017), information sharing and perceived privacy (Bugshan \& Attar, 2020), perceived risk (Farivar et al., 2017; Gan \& Wang, 2017), information quality (Cheng et al., 2019), social support and relationship quality (Molinillo et al., 2020), social norms (Shin, 2013), s-commerce construct (Hajli et al., 2014), familiarity (Gibreel et al., 2018; Cheng et al., 2019). Next section reviews related studies on eWoM.

\section{eWoM and It's Effect in Promoting S-Commerce}

eWoM is an important marketing tool with a significant impact on consumer choices. Indeed, experts believe that $76 \%$ of consumers currently trust peer recommendations. WoM communications became a valuable reference for consumers in deciding whether a product meets their needs or not. Thus, a person's recommendations are passed through verbal means in an informal manner rather than using mass media or traditional marketing means. eWoM, is defined by Hennig-Thurau et al. (2004) as "any positive or negative statement made by potential, actual, or former customers about a product or company, which is made available to a multitude of people and institutions for commercial and non-commercial activity" such as online reviews.

With the move to Web2.0, eWoM became more popular and it allowed users to create, edit, and distribute content. Accordingly, eWoM has more persuasive influence on customers toward 
s-commerce and can influence customers' behavior greater than any other means (Wang \& Yu, 2017). The influence of eWoM has been heavily investigated on different sectors in term of eWoM and loyalty (Gauri et al., 2008; Yoo et al., 2013), eWoM and social media (Chu \& Choi, 2011; Teng et al., 2014; Yan et al., 2016), eWoM and s-commerce.

The eWoM related s-commerce literature can be categorized into two streams: Studies that investigated causes of eWoM (see Table 1), and consequence of eWoM (Kim \& Park, 2013; Wang \& Yu, 2017; Gibreel et al., 2018; Yan et al., 2016; Coursaris et al., 2018; Sharma \& Crossler, 2014). Among these streams, our study focused on the first stream. Table 1 summarizes some recent studies on factors that impact eWoM in s-commerce behaviors. But unlike the many studies that focus on identifying characteristics of eWoM, our study investigates factors that lead to increase use of eWoM (see appendix 3 that shows how previous studies measure eWoM).

However, they focused on assessing consumers' intentions rather than the actual behavior; they proposed models that are not in line with marketing and information system success studies that posit value-satisfaction-loyalty chain influences customer's behavior (Rouibah et al., 2015). Also they did not try to reconcile their models with TAM which provide more parsimonious models that organize factors into the beliefs -attitude- behavior chain. And the proposed models also lacked consistency with the marketing and customer behavior literature that had proposed external factorsvalue-satisfaction-loyalty chain that influences customers to buy. Furthermore, they did not integrate important factors that affect positive eWoM use in s-commerce such as affective and utilitarian and hedonic motivation, trust factors (trust of internet/ Instagram, and trust toward people), and perceived risk in a single model. Furthermore, they do not provide rational for the choice of the selected factors using mixed method research. Indeed, the literature review of Zhang \& Benyoucef (2016) showed that only two studies among 77 studies used mixed methods.

Table 1. Recent studies on factors that affect eWoM in s-commerce

\begin{tabular}{|c|c|}
\hline Author (Year) & Theory and antecedents of intention to use eWoM \\
\hline Molinillo et al. (2020) & $\begin{array}{l}\text { Social Support theory, social identity theory: social support, community drivenness, } \\
\text { community identification, community trust }\end{array}$ \\
\hline Cheng et al. (2019) & $\begin{array}{c}\text { Interpersonal attraction theory: Customer trust toward, trust member, trust } \\
\text { disposition, quality of shared information, familiarity, endorsements by other } \\
\text { members, perceived similarity }\end{array}$ \\
\hline Mikalef et al. (2017) & $\begin{array}{c}\text { Theory of WoM and motivation theory: Purchase intention, socializing, personal } \\
\text { recommendation, product selection, information availability }\end{array}$ \\
\hline Yan et al. (2016) & $\begin{array}{l}\text { Cognitive cost theory: eWoM volume, eWoM rate extremism, eWoM integrity, } \\
\text { eWoM source credibility, eWoM usefulness, eWoM credibility }\end{array}$ \\
\hline Qin \& Kong (2015) & $\begin{array}{l}\text { TAM and trust theory: Perceived usefulness, perceived trustworthiness of } \\
\text { s-commerce in protecting users' privacy, perceived trustworthiness of other users' } \\
\text { competence }\end{array}$ \\
\hline Kim \& Park (2013) & $\begin{array}{l}\text { TRA and trust theory: Trust, reputation, size, information quality, transaction safety, } \\
\text { communication, economic feasibility, WoM referrals }\end{array}$ \\
\hline Mikalef et al. (2013) & $\begin{array}{l}\text { Motivation theory: Social media product browsing, utilitarian motivation, hedonic } \\
\text { motivation, convenience, information availability, product selection, customized } \\
\text { advertisement; trend discovery, socializing, adventure, authority and status }\end{array}$ \\
\hline Pöyry et al. (2013) & $\begin{array}{c}\text { Motivation theory: utilitarian motivation, hedonic motivation, participation, } \\
\text { browsing. }\end{array}$ \\
\hline Cheung et al. (2009) & $\begin{array}{l}\text { Dual process theory: argument strength, recommendation framing, recommendation } \\
\text { sidedness, source credibility, confirmation with prior belief, recommendation } \\
\text { consistency, recommendation rating, and perceived eWoM review credibility. }\end{array}$ \\
\hline
\end{tabular}




\section{Perceived Value and Perceived Enjoyment in S-Commerce and Their Relative Importance}

Researchers have advocated that consumers decision for purchase is driven by the utilitarian value (i.e. perceived value/ perceived usefulness) which is aim to maximum the value receives by a customer from functionalities of purchasing products (cf. Literature review studies: Zhang \& Benyoucef, 2016; Han et al., 2018). But the value was found to be more complex and the hedonic component (i.e. perceived enjoyment) was also proposed that involves more than utilitarian values (Hirschman \& Holbrook, 1982). The integration of both values enable a more complete evaluation of intention for purchasing in s-commerce (Shen, 2012; Pöyry et al., 2013; Zhang et al., 2018; Gan \& Wang, 2017) and eWoM (Mikalef et al., 2013). However, prior studies integrate both values in different ways, and thus do not comply with well-known theory models (e.g. TAM) and marketing studies. They linked utilitarian and hedonic values as: (a) mediating factors, and direct antecedents of intention to buy (Shen, 2012; Chen et al., 2017), (b) as mediating factors, and indirect antecedents of eWoM via the mediation of browsing (Mikalef et al., 2013), (c) as independent and indirect antecedents of referral intention (Pöyry et al., 2013), independent and indirect antecedents of urge to buy impulsively (Zhang et al., 2018), independent and direct antecedents of intention to buy (Gan \& Wang, 2017; Shin, 2013; Sharma \& Crossler, 2014).

Furthermore, these studies provide mixed results between those who found direct positive effect on intention to buy (Shen, 2012; Shin, 2013; Gan \& Wang, 2017; Chen et al., 2017) and indirect effect via the mediation of other factors (Mikalef et al., 2013; Pöyry et al., 2013), while other failed to find significant effect (Sharma \& Crossler, 2014). Likewise, the relative importance of utilitarian value vs. hedonic value is questioned in s-commerce when the two motivation factors are integrated. Zhang et al. (2018), Chen et al., (2017) and Shin (2013) found that the hedonic value has more impact on intention to buy than utilitarian value. While others found the opposite either for intention to buy (Shen, 2012; Mikalef et al., 2013; Pöyry et al., 2013; Gan \& Wang, 2017) or intention to use eWoM (Mikalef et al., 2013).

\section{The Role of Risk and Trust Perceptions in S-Commerce}

Furthermore, while past studies have identified several dimensions for perceived risks (financial, performance, social, physical, psychological, time loss, personal, privacy, and source) in e-commerce (Lim, 2003; Yang et al., 2015), none of the prior studies (Gan \& Wang, 2017; Rice \& Aydin, 1991) examined the effect of such type of risks on s-commerce adoption, see appendix 5 how previous s-commerce measure perceived risk. With the increase in security breaches most people with limited knowledge in internet security will not be encouraged to complete online transactions. Accordingly, trust is mandatory to overcome risk perceptions (Rouibah et al., 2016). Information researchers have conceptualized trust either in term of Mayer et al. (1995) vendor' attributes (ability, benevolence, and integrity), or McKnight et al. (1998) attributes that combines both vendors and consumers (individual disposition to trust, institution-based trust; and cognitive-based trust). Individual disposition to trust focuses on the individual personality characteristics that determine the readiness of the individual to trust. Institution-based trust focuses on the development of trust between individuals and vendors. This includes trust in the security features and system performance while cognition-based trust relied on one's first impressions or cognitive cues, as opposed to personal interactions with the other. Although there are very few exception (Cheng et al., 2019; Farivar et al., 2017) that focused on intention to purchase, the majority of prior s-commerce studies have focused on vendor' attributes trust or on individual trust or trust of the internet (Kim \& Park, 2013; Hajli et al., 2017; Akman \& Mishra, 2017; Gibreel et al., 2018; Farivar et al., 2017; Molinillo et al., 2020), see appendix 4 how trust constructs were operationalized. As these two components of trust (trust of internet/Instagram and trust toward other people) have more importance in the Arab collectivism culture, we alleviate this gap by including them for the first time as determinants of eWoM use in s-commerce context. 


\section{Arab Studies on E-Commerce and S-Commerce}

Most Arab studies focused mainly on social use of OSN (Rouibah, 2008), see appendix 2, and on e-commerce (e.g., Rouibah et al., 2015) and e-payment (e.g., Rouibah et al., 2016). But recently, there are attempts by researchers to investigate factors (Table 2) that affect s-commerce adoption from the business (Abed, 2020) and customer perspective (Gibreel et al., 2018; Doha et al., 2019; Bugshan \& Attar, 2020).

With regard to the objectives of our study, they found that several factors impact s-commerce intention to purchase from s-commerce web sites and Facebook (see Table 2 and appendix 1), including customer trust (Gibreel et al., 2018; Bugshan \& Attar, 2020), privacy risk perception (Bugshan \&

Table 2. Recent Arab studies on s-commerce adoption

\begin{tabular}{|c|c|}
\hline Author (Year) & Theory and antecedents of intention to use \\
\hline Bugshan \& Attar (2020) & $\begin{array}{r}\text { Social support theory and trust theory: s-commerce sharing information activities, } \\
\text { trust in sharing s-commerce, perceived privacy risk }\end{array}$ \\
\hline Doha et al. (2019) & $\begin{array}{r}\text { Consumers motivation theory: Utilitarian factors (perceived ease of use), economic } \\
\text { factors (user innovativeness, service innovativeness, perceived value) and social } \\
\text { factors (social capital, engagement, homophily, group fill) }\end{array}$ \\
\hline Gibreel et al. (2018) & $\begin{array}{r}\text { TAM and Trust theory: Familiarity, WoM, technical utility, governing from factors, } \\
\text { trust, perceived ease of use, perceived usefulness, intention to search }\end{array}$ \\
\hline Aladwani (2018) & $\begin{array}{r}\text { Consumer socialization theory and Electronic: demographic data (social media } \\
\text { experience of users, online spending), commerce quality research: perceived quality } \\
\text { of social support, perceived social commerce quality, initial attention, interaction } \\
\text { experience, initial evaluation, intention to buy }\end{array}$ \\
\hline
\end{tabular}

Attar, 2020) while their findings related to the effect of perceived value were conflicting (Doha et al., 2019; Gibreel et al., 2018). Furthermore, these studies focused on intention to purchase instead of the current behavior, ignoring the role of eWoM and perceived enjoyment in s-commerce, despite their importance in prior Arab e-commerce studies (Rouibah et al., 2016; Al-Debei et al., 2015). Accordingly, the role of these missing factors is questioned in s-commerce adoption.

\section{Unique Characteristics of the Arab Culture and It's Relation to S-Commerce}

The Arab World is large and consists of 22 countries spread out in the Middle East and North Africa. Most of these countries share similar religion, values and culture. Like any other Arab country, Kuwait share common cultural characteristics.

Firstly, Arabs score high on Hofstede Uncertainty Avoidance (UA) scale compare to western culture. UA refers to the extent to which the members of a culture feel threatened by ambiguous or unknown situations. Thus, Arab people are less risk takers than those in Westernized countries, and risk will be an important impediment on s-commerce adoption.

Secondly, Arab culture (Rouibah \& Hamdy, 2009) is highly social and more family oriented which makes people put more emphasis on group activities rather on individual ones. Rouibah et al. (2016) indicated that in a collectivist cultures, people are more influenced by the opinions of the group members they belong to and have more tendencies to share everything they believe will be useful and helpful for the group through e-WoM communications.

Third, Arab culture scores low on masculinity compared to Western Culture and thus is considered a feminine culture. This means that the dominant values in the society are caring for others and quality of life, and Arab people have more tendency to have fun and relaxation (Rouibah, 2008; Rouibah et al., 2016). Thus, Arabs have a need to enjoy what they do (considered a feminine trait) more than 
they want to be the best (viewed as a masculine trait). Accordingly, perceived enjoyment is expected to play an important role since Instagram combines both socialization and attractive features for e-commerce transactions.

And since purchasing online entail facing risks, Arabs tend to reduce such impacts using several means (Rouibah et al., 2016) including perceived enjoyment, and high trust toward other people. Thus, it is worth studying the combination of trust toward people, trust of the communication channel resembled here by internet/ Instagram, perceived risk, perceived enjoyment, perceived value, and satisfaction on eWoM use of s-commerce in a collectivist culture.

\section{THEORETICAL BASIS AND RESEARCH MODEL}

\section{Theoretical Basis}

Drawing on behavioral theories (TAM, TRA, and TPB) prior studies have shown that consumer intentions to engage in online transactions are significant predictors of consumers' actual behavior (Rouibah et al., 2016). TRA (figure 1.a) assumes that a consumer's Actual Behavior (AB) is decided by his or her Behavior Intention (BI), both of which are influenced by personal Attitude toward Behavior (AT) and Subjective Norm (SN). However, TRA does not involve objective constraint variables such as self-control and situational variables from outside of the system. TPB (figure 1.b) is an extension of TRA and includes Perceived Behavioral Control (PBC) to represent consumer perception of required resources and opportunities to perform the behavior of interest.

TAM assumes that the decision to use is based on external stimulus that drive a cognitive process response (PU and PEOU) to use, which in turn affects one' affective response (attitude). Finally, the affective response drives the behavioral response (intention to use and actual behavior). TAM (Figure 1.c) eliminated the constructs of subjective norms while keeping the construct of PBC in TPB. PBC is represented in TAM by PU and PEOU (Yang et al., 2015). Although TAM has been widely used in the context of e-commerce, prior literature review studies reported that it explain low values of consumer behavior intention (Mortenson \& Vidgen, 2016), and they called for additional factors. Aiming to elucidate the problem, researchers developed various forms of extended TAM and included several external factors such as perceived enjoyment (Rouibah, 2008), trust and risks (Rouibah et al., 2016; McKnight et al., 2017) since much empirical evidence has confirmed that these are important factors in e-shopping: Based on TRA and TPB, SN and PBC behavior are controlled by outside factors. Some researchers consider trust perceptions as representative of SN and perceived risk as representative of PBC in TAM (Yang et al., 2015). Finally, since the focus on this study is on post-adoption and not on pre-adoption, as the case of most s-commerce studies, this study replaces attitude by satisfaction and current behavior by eWoM. Therefore, the proposed model (Figure 2) is in line with the marketing and customer behavior literature that proposes a value-satisfaction-loyalty chain that influences customer's behavior (Rouibah et al., 2015).

\section{HYPOTHESIS DEVELOPMENT}

\section{Customer Satisfaction}

According to behavioural theories (TRA, TPB and TAM), satisfaction and current behaviour are often used as dependent variables in consumer purchasing research. Satisfaction relates to a specific transaction and is a function of all previous transactions. It occurs when perceptions related to current experiences surpass past expectations. Therefore, more satisfaction will lead to more customer use and intention to reuse s-commerce over Instagram. Use and satisfaction are two common measure of IS success. The information success model posits that use and user's satisfaction affect each other simultaneously (Delone \& McLean, 2003; Rouibah et al., 2015), but that use can only be achieved when other factors are present. Here we consider eWoM as a form of use. The collectivism dimension of the Arab culture makes people rely more on what other say and trust and therefore is more impacted 
Figure 1. TRA, TPB, TAM and the proposed research model

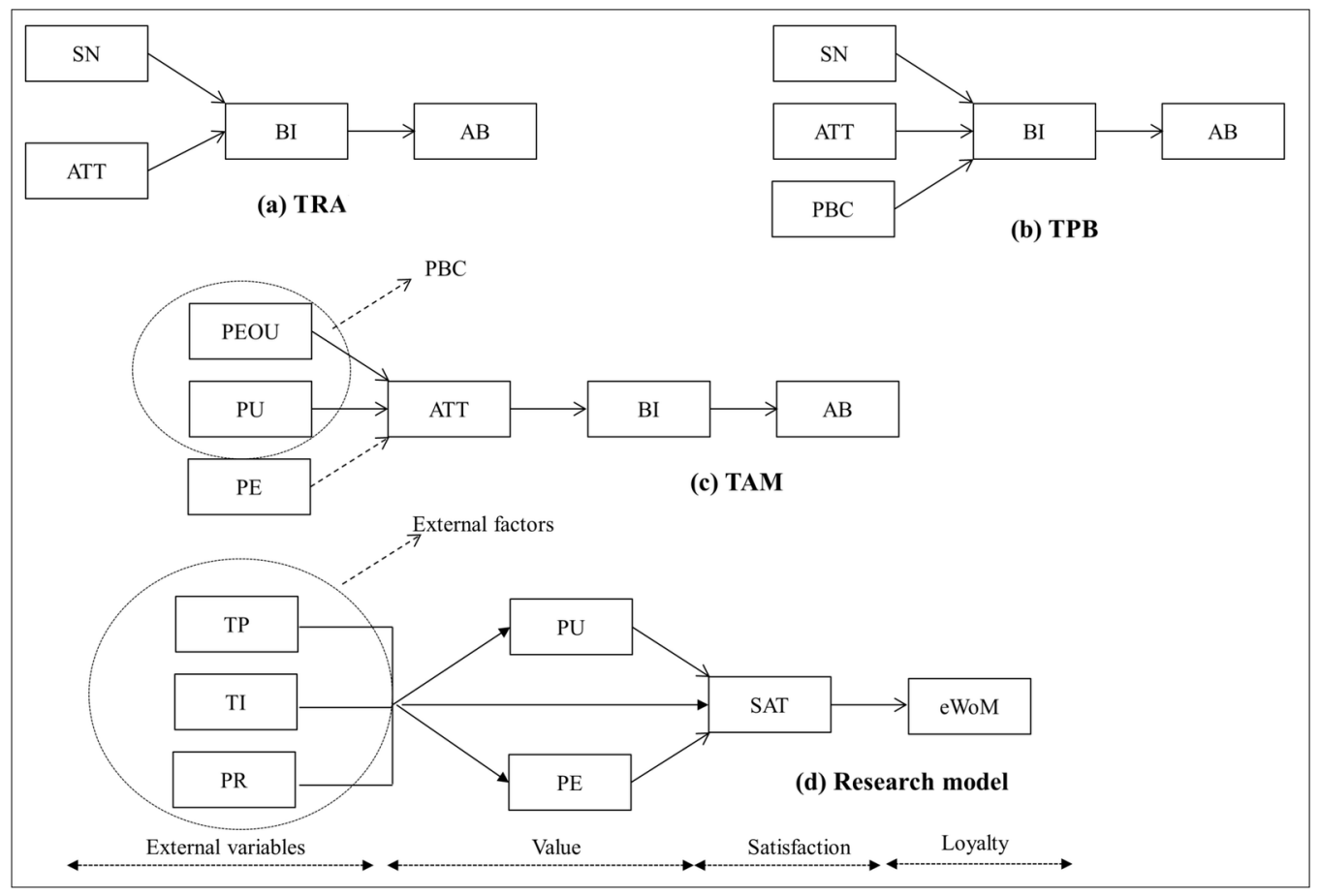

Figure 2. Research model

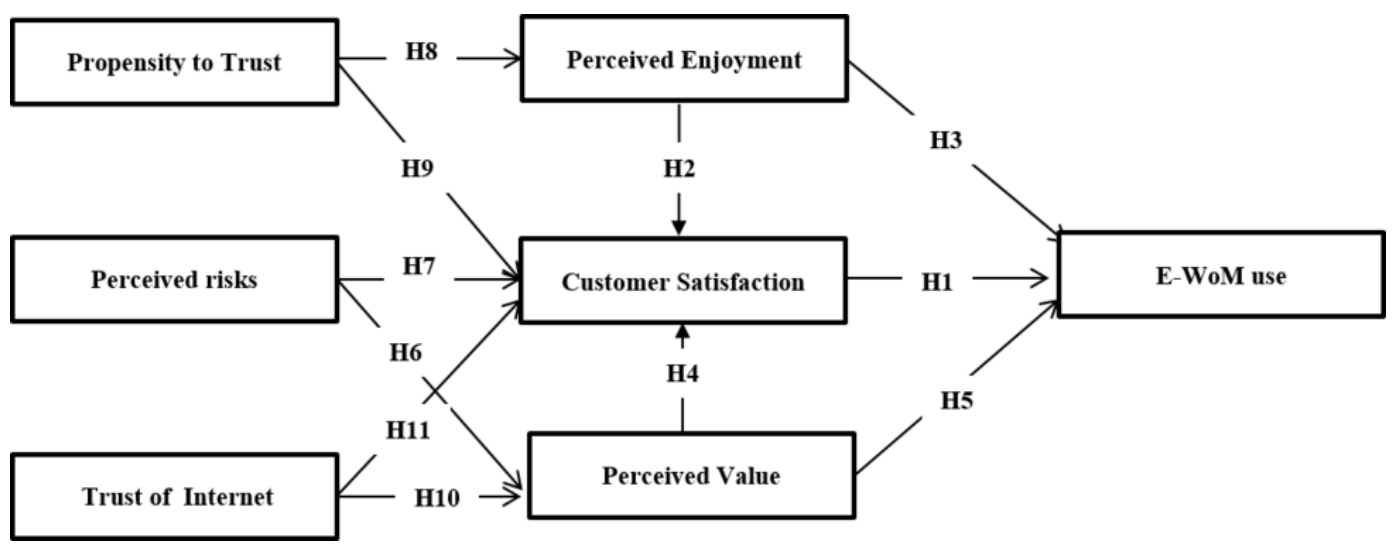

by eWoM when using Instagram. For example, Ghandor (2011) the CEO and founder of Aramex, a famous Arab logistic company, quoted " $\mathrm{eWoM}$ product evaluation and feedback expressed by customers are immediate, and instantaneous, therefore there is a need for immediate gratification'. He added that "exchanged product assessment by mean of eWoM would have a significant impact on potential customers/purchasers". In this study, a customer uses eWoM in case he/she feels information asymmetry, i.e. when he/she is not sure about the quality of products and needs additional information; he/she then relies on eWoM recommendations to reduce the risks of purchase. Thus, we posit, for the first time:

H1: Consumer satisfaction will positively influence eWoM use of s-commerce. 


\section{Perceived Enjoyment and Perceived Value}

Derived from the theory of flow, it perceived enjoyment refers to the value a customer receives in terms of subjective experiences of fun, and playfulness (Holbrook \& Hirschman, 1982). It aims to fulfill and satisfy customers hedonic need and search of emotions and obtain pleasure, such as happiness, joy and fantasy during the shopping procedure (Mikalef et al., 2013). Instagram is considered as a hedonic system and an OSN for s-commerce. Instagram includes several features that increase users' enjoyment such as pictures, interacting with others to seek product recommendations. Consequently, the sense of enjoyment increases satisfaction and current usage. Unlike the only study of Mikalef et al. (2013) who posited perceived enjoyment indirectly influences eWoM via the mediation of browsing, we propose here for the first time that perceived enjoyment will influence customer satisfaction and increase eWoM in a way to motivate the use of s-commerce on Instagram more specifically. We then infer for the first time:

H2: Perceived enjoyment positively influences customer satisfaction.

H3: Perceived enjoyment positively influences e-WoM use of s-commerce.

Perceived value is more of a complex construct that refers to what is received and given, and this includes the consumers overall evaluation of the utility of the products/ services (Rouibah et al., 2015; Zeithaml, 1988). It also refers to the consumer's overall perception of the product/service based on the considerations of its benefits and the desired sacrifice to acquire and/or use it (Rouibah et al., 2015). The information success model for the e-commerce context (Rouibah et al., 2015; Delone \& McLean, 2003) posits that perceived value affect satisfaction. We replicate this in the s-commerce context and based on the social characteristics of Arab culture, and also posit for the first time that perceived value will affect eWoM in using s-commerce over Instagram. Consequently we infer:

H4: Perceived value positively influences customer satisfaction.

H5: Perceived value positively influences e-WoM use of s-commerce.

Unlike the western culture that scores higher on masculinity, Arab culture scores low, and thus is considered a feminine culture This means that the dominant values in the society are caring for others and quality of life. Thus, Arabs have a need to like and enjoy what they do (considered a feminine trait) more than craving to be the best, viewed as a masculine trait (Rouibah et al., 2016). Consequently, we expect the relative impact of perceived enjoyment will be larger than that of perceived value. Accordingly, the following hypothesis is proposed for the first time:

H5a: Perceived enjoyment will have strong positive influence on e-WoM use of s-commerce than perceived value.

\section{Perceived Risks}

Perceived risk relates to the expectation of uncertainty and perceived consequences from the purchase of goods and services, fraud and product quality (Rouibah et al., 2016; Forsythe et al., 2006). It is also related to the consumer's negative perception that the online vendor will not fulfill its security requirements (Rouibah et al., 2016). Recent studies (Farivar et al., 2017; Bugshan \& Attar, 2020) have found that perceived risk plays more important role than positive factors (e.g. customer trust). In the s-commerce context, these online vendors are mainly micro businesses who work without any third parties and mediating agents. They don't have rigorous return policy and less experience in customer service than B2C companies. Thus, customers may feel different risks (such as quality of product, lack of good feel of product, after-sale service, etc.). Because of the high uncertainty 
avoidance characteristic laden in the Arab culture, Arab consumers who are happy with more face to face types of interactions will negatively perceive the impact of risk perception on perceived value and satisfaction in s-commerce over Instagram. A study in Kuwait about critical success factors of B2C success found that system security exerts the strongest effect on the intention to reuse e-commerce (Rouibah et al., 2015). For the first time in s-commerce research, this study posits that perceived risk is composed of six types (price, time loss, quality, lack of good feel of product, after-sale service, and value) (Lim, 2003; Yang et al., 2015) will negatively affect both perceived value and consumer's satisfaction. Thus, we posit:

H6: Perceived risk negatively affects a consumer's perceived value.

H7: Perceived risk negatively affects a consumer's satisfaction toward using s-commerce.

\section{Trust Factors: Trust Toward Other People and Trust of the Internet}

Trust is mandatory to reduce risk perceptions and conduct business in online environment. As discussed earlier, and unlike prior studies that focused on type of trust (vendor' attributes trust or on individual trust or trust of the internet), we follow McKnight et al. (1998) how conceptualize trust as both individual disposition to trust attributes (trust toward other people) and institution-based trust -in term of trust of internet/Instagram.

Individuals differ in making consideration on their general propensity to trust others due to cultural background, personality type, religious beliefs, and past experiences. Trust toward other people refers to the extent character that a person demonstrates in a consistent tendency to depend on others across a broad spectrum of situations and individuals (McKnight et al., 1998). This is important to the proliferation of s-commerce that is based on dependencies of customers with others to promote buying products/ services based on trust. In this stream we adopt the measures of Cheung \& Lee (2000) who measured trust toward other people in terms four items (existing trust among family members, friends are generally trustworthy, people of a community trust each other, and living in a high trust society), which are more suitable for the context of s-commerce. Unlike (Cheng et al., 2019; Farivar et al., 2017) who posited that customer trust influences directly intention to adopt. We advocate here that customers with a high trust towards others will perceive risk to be less threatening and thus increase customer perceived value and his satisfaction. Therefore for the first time we posit:

H8: Trust toward other people positively affects a consumer's perceived value.

H9: Trust toward other people positively affects a consumer's satisfaction toward s-commerce.

Prior research found risk concerns, were based on customers' perceptions and not on objective measures because the average Internet user does not have enough knowledge to distinguish between the different security features present in a particular OSN. Prior research suggests that customer's trust regarding the Internet and on e-commerce providers represent a prerequisite for completing online transactions (Cheung \& Lee, 2000) but as Instagram enables many individuals to sell online, this study focuses solely on the effect of trusting the internet/Instagram that a customer holds, and we advocate for the first time that normal people who trust internet and Instagram technology will have high perceived value and satisfaction. Thus, for the first time we infer:

H10: Trusting the Internet/Instagram positively affects a consumer's perceived value of s-commerce.

H11: Trusting the Internet/Instagram positively affects a consumer's satisfaction toward using s-commerce. 


\section{RESEARCH METHODOLOGY}

This used a mixed method research (Venkatesh et al., 2013) to shed light on eWoM use in s-commerce involving both a qualitative study and quantitative study.

\section{Qualitative Study: Questionnaire Development}

We used a survey to empirically examine and evaluate the 12 research hypotheses. For this purpose, we developed an instrument-a questionnaire-to measure consumers' perceptions of the used constructs. In building this research model, the authors adopted a process that followed four steps in building the research model (Hong et al., 2013). First, authors conducted an extensive literature review on s-commerce use, adoption and eWoM (see appendix 1). Second, we conducted a qualitative approach that involves interviewing 102 customers who are active users of s-commerce over Instagram. Participants were asked to state, in free format, potential factors that drive them in using s-commerce on Instagram. Two IS researchers did the coding/classification process according to the elicitation method of Limayem \& Hirt (2003). A list of 17 drivers of s-commerce adoption by customers was identified (Rouibah \& Al-Qirim, 2017). Third, the main characteristics of the Arab culture were also identified as highlighted above and the seven variables, depicted in the research model, were selected from this list. Finally, this study developed a survey instrument, which was further validated by four IS faculty members in order to examine the questionnaire for validity, completeness, and readability.

\section{Construct Measurements}

Items were reused from past valid studies in order to ensure content validity (see Table 4). A questionnaire was designed reflecting the seven constructs, including three trap questions in order to check for the reliability of the questionnaire. Items were measured on a five-point Likert scale ranging from (1) for strongly disagree to (5) for strongly agree. Demographic questions relating to characteristics of respondents such as gender, age, citizenship, job title, education level, type of Instagram use, and frequency of Instagram use were also included.

\section{Sample and Procedure of Data Collection}

Because we borrowed item-constructs from past studies, originally published in English, all survey items, were translated and back translated following a well established procedures (cf., Lowry et al., 2011) by a researcher fluent in both English and Arabic and two additional professors were used later on to ensure the accuracy of the translation. The population consists of all adults in Kuwait. Data was collected through Quatrics.com and snowball technique was used (Biernacki \& Waldorf, 1981) to distribute the URL for the target population. The survey link was promoted by invitation e-mails to thousands of people who were asked to promote it in their networks. Paticipants contacted other friends, familly members who were encouraged to answer the questionnaire and to distribute the URL to others. All questionnaires were sent by e-mail and to four popular OSN tools that are highly used in Kuwait (Instagram, WhatsApp, Twitter, and facebook). Among 2,000 distributed questionnaires we succeeded in collecting 1368 responses, and discarded 525 (257 were either incomplete or did not use Instagram, 192 did not comply with the trap questions, and 76 were completed in less than the average time needed to complete the survey). Accordingly, this study used 843 questionnaires to validate the research model.

\section{Demographic Data}

Table 3 displays the profile of the respondents. All participants have already used and continue to use Instagram for s-commerce for diverse purchasing. 53.2\% used it several times per year, while $33.1 \%$ used it one time per month against $14 \%$ that used it for several times per month. Among participants, $49 \%$ have used it to purchase clothes, and $39.6 \%$ for health and beauty products, which increase the reliability of this study. 
Table 3. Profile of respondents and s-commerce behavior $(n=843)$

\begin{tabular}{|c|c|c|c|c|c|}
\hline Measure & Item & Percentage & Measure & Item & Percentage \\
\hline \multirow{2}{*}{ Gender } & Male & 16.5 & \multirow{2}{*}{ Nationality/Citizenship } & Kuwaiti & 92.8 \\
\hline & Female & 83.5 & & Non-Kuwaiti & 7.2 \\
\hline \multirow{5}{*}{$\begin{array}{l}\text { Position of } \\
\text { respondents }\end{array}$} & Student & 66.7 & \multirow{5}{*}{ Education Level } & $\begin{array}{c}\text { High school \& } \\
\text { lower }\end{array}$ & 29.9 \\
\hline & Employee & 26.8 & & Diploma degree & 10.4 \\
\hline & Job seeker & 3.3 & & $\begin{array}{c}\text { Bachelor } \\
\text { degree }\end{array}$ & 56.1 \\
\hline & \multirow{2}{*}{ Retired } & \multirow[t]{2}{*}{3.2} & & Master degree & 2.3 \\
\hline & & & & Ph.D. Degree & 1.3 \\
\hline \multirow{8}{*}{$\begin{array}{l}\text { Frequency of } \\
\text { s-commerce } \\
\text { behavior }\end{array}$} & \multirow{3}{*}{$\begin{array}{c}\text { Several times } \\
\text { per year }\end{array}$} & \multirow[t]{3}{*}{53.2} & \multirow{8}{*}{ Type of Instagram use } & Buy Clothes & 49.11 \\
\hline & & & & $\begin{array}{c}\text { Buy health and } \\
\text { beauty }\end{array}$ & 39.62 \\
\hline & & & & $\begin{array}{c}\text { Use for } \\
\text { entertainment }\end{array}$ & 44.16 \\
\hline & \multirow{2}{*}{$\begin{array}{l}\text { One time per } \\
\text { month }\end{array}$} & \multirow[t]{2}{*}{33.1} & & $\begin{array}{l}\text { Buy sporting } \\
\text { goods }\end{array}$ & 11.39 \\
\hline & & & & $\begin{array}{l}\text { Buy computers } \\
\text { and electronics }\end{array}$ & 10.9 \\
\hline & \multirow{2}{*}{$\begin{array}{l}\text { Several times } \\
\text { per month }\end{array}$} & \multirow[t]{2}{*}{10.7} & & Buy books & 10.08 \\
\hline & & & & Online game & 6.52 \\
\hline & $\begin{array}{l}\text { One time per } \\
\text { week }\end{array}$ & 3 & & Buy cars & 3.20 \\
\hline
\end{tabular}

\section{ANALYSIS AND RESULTS}

Data analysis was performed using LISREL in conjunction with SPSS for the assessment of the measurement model and the structural model.

\section{Measurement Model}

SEM technique was applied using LISREL, and following the steps of Rouibah \& Hamdy (2009): (i) We first assess and then fix the model before SEM is applied; (ii) modify the model and create the best measurement model; and (iii) analyze and test the SEM path relationship between the model constructs. Factor analysis technique was employed through SPSS 22, with VARIMAX rotation to remove any redundancy that might exist between items, and to identify the interrelationships among constructs related to the underlying collected data.

\section{Assessing Construct Validity and Reliability}

Before applying LISREL, authors assessed the convergent validity (measured by Cronbach's $\alpha$, composite reliability and average variance extracted) and discriminant validity of the structural model, which were achieved through factor analysis in conjunction with LISREL. As shown in Table 4 factor analysis resulted in seven factors that accounted for $71.51 \%$ of the total variance, as guided by Hair et al. (1998) each of the factors met the base criteria for retention as follows: (i) Items defining the various factors all had communalities greater than 0.50; (ii) Extracted factors accounted for greater 
than $50 \%$ of the variance in their sets of items; (iii) all factors have Eigen-values greater than 1.0; (iv) all item loadings were greater than 0.50 ; and (v) all factors are clearly interpretable.

Of the 29 items in the original list of items (see appendix 2), 5 items were deleted since they do not satisfy the above criteria. Items discarded are (see Table 4): PV4, PT1, PR1, PR2, and PR5. Table 4 shows the items retained, the seven-factor loadings, and the extracted variance. In addition, two items from eWoM (CS3 and CS4) and two from intention (CS5 and CS6) loaded together with satisfaction and then merged together. Table 4 shows that all items loadings were greater than 0.50 level for each construct (Hair et al., 1998). Cronbach's alpha coefficients indicate that each construct exhibits strong internal reliability (all above 0.70 ). The overall reliability coefficient Cronbach's $\alpha$ were more than $0.732 \%$ (Hair et al., 1998). The composite reliability of all constructs are varying from 0.70 to 0.82 , and therefore are within the range of the recommendations and larger than 0.70 cut-off (Fornell \& Larcker, 1981), and thus supporting convergent validity. All values of Average Variance Extracted (AVEs) in Table 4 vary from 0.51 to 0.82 , which were above the 0.50 proxy (Fornell \& Larcker, 1981; Hair et al., 1998).

Discriminant validity: according to Fornell \& Larcker (1981), constructs have adequate discriminant validity if the square root of the AVE for a construct is higher than the variance shared between the constructs and other constructs in the model. As it is seen in Table 5, the shared variance $\left(\mathrm{r}^{2}\right)$ among variables, obtained by squaring the correlations were less than the values of AVE, which further ensures the discriminant validity of the research model.

\section{Model Fit}

We used LISREL to test the research hypotheses. The fit indices of the measurement model show a converged and reasonably fit indices $\left(\chi^{2}=1168.5, \mathrm{DF}=285 ; \chi^{2} / \mathrm{DF}=4.1, \mathrm{NFI}=0.96, \mathrm{NNFI}=0.97\right.$, $\mathrm{CFI}=0.97, \mathrm{RMSR}=0.073, \mathrm{GFI}=0.91$ and $\mathrm{AGFI}=0.88)$. In sum, factor loading coefficients, squared multiple correlations, composite reliability, AVE, and model fit indices suggest that the measured variables explain further about the variances of corresponding latent constructs, supporting the validity of the measures (Hair et al., 1998).

\section{Model Validation and Results}

Figure 3 reports the path coefficients (betas, $\beta$ s) as well as variance $\left(R^{2}\right)$ values explained by the research model. In addition, Table 6 summarizes the hypotheses, the path coefficients (betas, $\beta \mathrm{s}$ ), and the $t$-values for each path. Of the 12 hypotheses, three (03) associations were not verified and were insignificant. These are H5, H6, and H9.

Perceived enjoyment and customer satisfaction lead to higher eWoM use, which contributes to explaining $32 \%$ of its variance. Among these two variables, satisfaction $(\beta=0.60)$ exerts the strongest impact on eWoM use. It is also clear that the effect of perceived enjoyment $\left(0.42+0.25^{*} 0.606=0.5715\right)$ on eWoM use is larger than the effect of perceived value $(0.30 * 0.606=0.1818)$. Furthermore, perceived enjoyment, perceived value and trust of internet have positive effect on satisfaction, while perceived risk has negative effect and trust toward people has no effect. The four variables explain $61.9 \%$ in the variance of satisfaction. Among these variables, trust of the internet $(\beta=0.46)$ exerts the strongest effect on satisfaction, followed by perceived value, perceived enjoyment, and last by perceived risk. Trust toward people increases perceived enjoyment and explains $21.4 \%$ of its variance. Trust of internet/ Instagram increases perceived value and contributes to explain $30.6 \%$ of its variance.

Our research model is a fully mediated mode because it does not predict any direct effects of trust towards people, trust of internet/ Instagram and perceived risks on eWoM use.

\section{DISCUSSION AND CONTRIBUTIONS}

This study has four main contributions for both research and practice. Our findings contribute to the existing literature in four ways. 
Table 4. Measures, loadings, means, SD, Cronbach a, CRs and AVEs

\begin{tabular}{|c|c|c|c|c|c|c|c|c|c|c|c|c|c|c|}
\hline \multirow{2}{*}{\begin{tabular}{|c|} 
Factors \\
$\begin{array}{c}\text { Perceived Value } \\
\text { (PV)(Forsythe et } \\
\text { al., 2006) }\end{array}$ \\
\end{tabular}} & \multirow{2}{*}{\begin{tabular}{|c|}
$\begin{array}{c}\text { Number } \\
\text { of Item } \\
\text { deleted }\end{array}$ \\
\end{tabular}} & \multirow[t]{2}{*}{ Item } & \multicolumn{7}{|c|}{ Standardized loadings } & \multirow[t]{2}{*}{ Mean } & \multirow[t]{2}{*}{ SD } & \multirow{2}{*}{$\underset{\alpha}{\text { Cronbach }}$} & \multirow{2}{*}{$\begin{array}{l}\text { Composite } \\
\text { reliability }^{1}\end{array}$} & \multirow[t]{2}{*}{$\mathbf{A V E}^{2}$} \\
\hline & & & 1 & 2 & 3 & 4 & 5 & 6 & 7 & & & & & \\
\hline $\begin{array}{l}\text { PV1: Compared } \\
\text { to the fee I need } \\
\text { to pay, the use } \\
\text { of Instagram for } \\
\text { e-shopping offers } \\
\text { value for money }\end{array}$ & & PV1 & .258 & .217 & .720 & -.109 & .091 & .113 & .067 & 3.299 & 0.919 & 0.808 & & \\
\hline $\begin{array}{l}\text { PV2: Compared } \\
\text { to the effort I } \\
\text { need to put in, the } \\
\text { use of Instagram } \\
\text { for e-shopping is } \\
\text { beneficial to me }\end{array}$ & 1 & PV2 & .233 & .112 & .830 & .006 & .083 & .092 & .047 & 3.437 & 0.917 & & 0.73 & 0.73 \\
\hline $\begin{array}{l}\text { PV3: Compared } \\
\text { to the time I need } \\
\text { to spend, the use } \\
\text { of Instagram for } \\
\text { e-shopping is } \\
\text { worthwhile to me }\end{array}$ & & PV3 & .229 & .163 & .849 & -.024 & .076 & .102 & .021 & 3.421 & 0.921 & & & \\
\hline \multicolumn{15}{|l|}{$\begin{array}{l}\text { Trust towards } \\
\text { people(TP) } \\
\text { (Cheung \& Lee, } \\
\text { 2000) }\end{array}$} \\
\hline $\begin{array}{l}\text { TP2: My friends } \\
\text { are generally } \\
\text { trustworthy }\end{array}$ & & PT2 & -.024 & .039 & -.052 & .090 & .105 & .127 & .727 & 4.128 & 0.752 & \multirow[t]{3}{*}{0.732} & & \\
\hline $\begin{array}{l}\text { TP3: People of } \\
\text { my community } \\
\text { trust each other }\end{array}$ & 1 & PT3 & .057 & .028 & .090 & .006 & .054 & .022 & .855 & 3.606 & 0.831 & & 0.73 & 0.51 \\
\hline $\begin{array}{l}\text { TP4: Overall, I } \\
\text { am living in a } \\
\text { high trust society }\end{array}$ & & PT4 & .160 & .041 & .076 & -.057 & -.058 & .074 & .768 & 3.401 & 0.997 & & & \\
\hline \multicolumn{15}{|l|}{$\begin{array}{l}\text { Trust of } \\
\text { Internet (TRIN) } \\
\text { (Schaupp et al., } \\
\text { 2010) } \\
\end{array}$} \\
\hline $\begin{array}{l}\text { TRIN1: } \\
\text { Instagram has } \\
\text { safeguards to } \\
\text { make me feel } \\
\text { comfortable using } \\
\text { it for e-shopping }\end{array}$ & & TRIN1 & .195 & .140 & .143 & -.054 & .130 & .742 & .075 & 3.089 & 0.980 & \multirow[t]{3}{*}{0.755} & & \\
\hline $\begin{array}{l}\text { TRIN2: I feel } \\
\text { assured that legal } \\
\text { and technological } \\
\text { structures } \\
\text { adequately } \\
\text { protect me from } \\
\text { e-shopping } \\
\text { problems }\end{array}$ & 0 & TRIN2 & .213 & .061 & .049 & -.122 & .017 & .775 & .144 & 2.903 & 1.060 & & 0.71 & 0.53 \\
\hline $\begin{array}{l}\text { TRIN3: In } \\
\text { general, the } \\
\text { Internet is a } \\
\text { robust and safe } \\
\text { environment } \\
\text { in which to } \\
\text { complete } \\
\text { e-shopping } \\
\text { transactions }\end{array}$ & & TRIN3 & .362 & .121 & .125 & -.199 & .068 & .706 & .056 & 2.888 & 0.983 & & & \\
\hline $\begin{array}{l}\text { Perceived Risks } \\
\text { (PR) (Lim, 2003) }\end{array}$ & & & & & & & & & & & & & & \\
\hline
\end{tabular}


Table 4.Continued

\begin{tabular}{|c|c|c|c|c|c|c|c|c|c|c|c|c|c|c|}
\hline \multirow{2}{*}{$\begin{array}{c}\text { Factors } \\
\begin{array}{c}\text { Perceived Value } \\
\text { (PV)(Forsythe et } \\
\text { al., 2006) }\end{array}\end{array}$} & \multirow{2}{*}{$\begin{array}{l}\text { Number } \\
\text { of Item } \\
\text { deleted }\end{array}$} & \multirow[t]{2}{*}{ Item } & \multicolumn{7}{|c|}{ Standardized loadings } & \multirow[t]{2}{*}{ Mean } & \multirow[t]{2}{*}{ SD } & \multirow{2}{*}{$\begin{array}{c}\text { Cronbach } \\
\alpha\end{array}$} & \multirow{2}{*}{$\begin{array}{l}\text { Composite } \\
\text { reliability }^{1}\end{array}$} & \multirow[t]{2}{*}{$\mathbf{A V E}^{2}$} \\
\hline & & & 1 & 2 & 3 & 4 & 5 & 6 & 7 & & & & & \\
\hline $\begin{array}{l}\text { PR3: I am } \\
\text { worried that } \\
\text { products } \\
\text { sold through } \\
\text { Instagram } \\
\text { accounts are } \\
\text { fake, copied or } \\
\text { imitation products }\end{array}$ & & PR3 & -.134 & .035 & -.012 & .820 & .063 & -.093 & .033 & 3.985 & 0.864 & 0.801 & & \\
\hline $\begin{array}{l}\text { PR4: I am } \\
\text { worried that the } \\
\text { products I buy } \\
\text { from Instagram } \\
\text { accounts do } \\
\text { not meet my } \\
\text { expectations due } \\
\text { to being unable } \\
\text { to touch it or } \\
\text { give it a trial face } \\
\text { to face }\end{array}$ & 3 & PR4 & -.133 & .059 & -.059 & .822 & .089 & -.100 & .011 & 4.084 & 0.875 & & 0.75 & 0.58 \\
\hline $\begin{array}{l}\text { PR6: I am } \\
\text { worried about } \\
\text { the value of } \\
\text { the product I } \\
\text { purchase through } \\
\text { Instagram } \\
\text { accounts does not } \\
\text { meet its price }\end{array}$ & & PR6 & -.036 & -.015 & -.026 & .823 & -.021 & -.088 & .001 & 3.858 & 0.829 & & & \\
\hline \multicolumn{15}{|l|}{$\begin{array}{l}\text { Perceived } \\
\text { enjoyment (PE) } \\
\text { (Agarwal \& } \\
\text { Karahanna, } \\
\text { 2000) }\end{array}$} \\
\hline $\begin{array}{l}\text { PE1: I have fun } \\
\text { interacting with } \\
\text { Instagram }\end{array}$ & & PE1 & .208 & .848 & .181 & .021 & .075 & .088 & .053 & 3.987 & 0.730 & 0.894 & & \\
\hline $\begin{array}{l}\text { PE2: Using } \\
\text { Instagram } \\
\text { provides me with } \\
\text { a lot of enjoyment }\end{array}$ & 0 & PE2 & .189 & .872 & .123 & .043 & .126 & .104 & .055 & 3.976 & 0.734 & & 0.73 & 0.82 \\
\hline $\begin{array}{l}\text { PE3: I enjoy } \\
\text { using Instagram }\end{array}$ & & PE3 & .237 & .850 & .171 & .029 & .063 & .120 & .024 & 3.867 & 0.802 & & & \\
\hline $\begin{array}{l}\text { Consumer } \\
\text { Satisfaction; } \\
2 \text { items from } \\
\text { (Murray \& } \\
\text { Howat, 2002); } \\
\text { and } 4 \text { items from } \\
\text { the qualitative } \\
\text { study }\end{array}$ & & & & & & & & & & & & & & \\
\hline
\end{tabular}

continued on following page 


\begin{tabular}{|c|c|c|c|c|c|c|c|c|c|c|c|c|c|c|}
\hline \multirow{2}{*}{\begin{tabular}{|c|} 
Factors \\
$\begin{array}{c}\text { Perceived Value } \\
\left(\begin{array}{c}\text { PV)(Forsythe et } \\
\text { al., 2006) }\end{array}\right.\end{array}$ \\
\end{tabular}} & \multirow{2}{*}{$\begin{array}{c}\text { Number } \\
\text { of Item } \\
\text { deleted }\end{array}$} & \multirow[t]{2}{*}{ Item } & \multicolumn{7}{|c|}{ Standardized loadings } & \multirow[t]{2}{*}{ Mean } & \multirow[t]{2}{*}{ SD } & \multirow{2}{*}{$\underset{\alpha}{\text { Cronbach }}$} & \multirow{2}{*}{$\begin{array}{l}\text { Composite } \\
\text { reliability }^{1}\end{array}$} & \multirow[t]{2}{*}{$\mathbf{A V E}^{2}$} \\
\hline & & & 1 & 2 & 3 & 4 & 5 & 6 & 7 & & & & & \\
\hline $\begin{array}{l}\text { CS1: Based } \\
\text { on my prior } \\
\text { experience, I am } \\
\text { satisfied with my } \\
\text { shopping through } \\
\text { Instagram }\end{array}$ & & US1 & .752 & 173 & .164 & -.126 & .148 & .240 & .065 & 3.351 & 0.926 & 0.832 & & \\
\hline $\begin{array}{l}\text { CS2: Based } \\
\text { on my prior } \\
\text { experience, I } \\
\text { think purchasing } \\
\text { through } \\
\text { Instagram } \\
\text { accounts is a wise } \\
\text { choice }\end{array}$ & 0 & US2 & .752 & .115 & .200 & -.168 & .104 & .235 & .089 & 3.051 & 0.904 & & & \\
\hline $\begin{array}{l}\text { CS3: I am } \\
\text { satisfied with the } \\
\text { recommendations } \\
\text { of eWoM } \\
\text { (relatives and } \\
\text { friends) about } \\
\text { purchasing } \\
\text { products from } \\
\text { Instagram } \\
\text { accounts }\end{array}$ & & US3 & .667 & .148 & .131 & .004 & .278 & .143 & .055 & 3.479 & 0.915 & & & \\
\hline $\begin{array}{l}\text { CS4: I am } \\
\text { satisfied with } \\
\text { the products } \\
\text { I purchased } \\
\text { from Instagram } \\
\text { accounts and } \\
\text { introduced to me } \\
\text { by eWoM from } \\
\text { friends }\end{array}$ & & US4 & .717 & 158 & .115 & -.026 & .242 & .071 & .059 & 3.416 & 0.928 & & 0.82 & 0.66 \\
\hline $\begin{array}{l}\text { CS5: Based } \\
\text { on my prior } \\
\text { experience, I } \\
\text { am planning } \\
\text { to repurchase } \\
\text { through } \\
\text { Instagram } \\
\text { accounts in the } \\
\text { future }\end{array}$ & & US5 & .808 & 162 & .219 & -.081 & .121 & .154 & .038 & 3.346 & 0.948 & & & \\
\hline $\begin{array}{l}\text { CS6: Based on } \\
\text { my past purchase } \\
\text { experiences, } \\
\text { I will reuse } \\
\text { Instagram } \\
\text { accounts to } \\
\text { repurchase in the } \\
\text { future }\end{array}$ & & US6 & .801 & 149 & .189 & -.129 & .144 & .181 & .031 & 3.287 & 0.906 & & & \\
\hline \multicolumn{15}{|l|}{$\begin{array}{l}\text { e-WOM(Lee, } \\
\text { 2014) }\end{array}$} \\
\hline $\begin{array}{l}\text { eWoM1: When } \\
\text { I am not sure } \\
\text { about the quality } \\
\text { of products I } \\
\text { rely on eWoM } \\
\text { recommendations } \\
\text { on Instagram } \\
\text { accounts }\end{array}$ & & eWOM1 & 207 & .075 & .104 & .058 & .857 & .013 & -.047 & 3.719 & 0.899 & 0.797 & & \\
\hline $\begin{array}{l}\text { eWoM2: } \\
\text { Whenever I } \\
\text { required product } \\
\text { information, I } \\
\text { first seek eWoM } \\
\text { recommendations } \\
\text { on Instagram } \\
\text { accounts } \\
\end{array}$ & 0 & eWOM2 & .250 & .086 & .024 & .102 & .855 & .053 & .018 & 3.756 & 0.884 & & 0.7 & 0.61 \\
\hline $\begin{array}{l}\text { eWoM3: I } \\
\text { consider online } \\
\text { customer reviews } \\
\text { when I make } \\
\text { a purchase } \\
\text { decision about a } \\
\text { product through } \\
\text { Instagram } \\
\text { accounts }\end{array}$ & & eWOM3 & .228 & .082 & .100 & -.014 & .626 & .134 & .154 & 3.546 & 0.823 & & & \\
\hline
\end{tabular}


Table 5. Correlation matrix of principle constructs [ ${ }^{\mathrm{a} C R},{ }^{\mathrm{b}} \mathrm{AVE}$, ${ }^{\mathrm{c}}$ Correlation, ${ }^{\mathrm{d}}$ Square correlation]

\begin{tabular}{|c|c|c|c|c|c|c|c|}
\hline \multirow{2}{*}{ Construct } & \multicolumn{7}{|c|}{ Correlation matrix } \\
\hline & 1 & 2 & 3 & 4 & 5 & 6 & 7 \\
\hline 1-Trust toward people & $\begin{array}{l}0.73^{\mathrm{a}} \\
0.51^{\mathrm{b}}\end{array}$ & & & & & & \\
\hline 2- Perceived risk (PR) & $\begin{array}{l}0.011^{\mathrm{c}} \\
0.000^{\mathrm{d}}\end{array}$ & $\begin{array}{l}0.75 \\
0.58\end{array}$ & & & & & \\
\hline 3-Trust of internet (TINT) & $\begin{array}{l}0.263 \\
0.069\end{array}$ & $\begin{array}{l}-0.400 \\
0.016\end{array}$ & $\begin{array}{l}0.71 \\
0.53\end{array}$ & & & & \\
\hline 4-Perceived enjoyment (PE) & $\begin{array}{l}0.163 \\
0.027\end{array}$ & $\begin{array}{l}0.012 \\
0.000\end{array}$ & $\begin{array}{l}0.418 \\
0.175\end{array}$ & $\begin{array}{l}0.73 \\
0.82\end{array}$ & & & \\
\hline 5-Perceied value (PV) & $\begin{array}{l}0.183 \\
0.033\end{array}$ & $\begin{array}{l}-0.137 \\
0.019\end{array}$ & $\begin{array}{l}0.429 \\
0.184\end{array}$ & $\begin{array}{l}0.491 \\
0.241\end{array}$ & $\begin{array}{l}0.73 \\
0.73\end{array}$ & & \\
\hline 6-Satisfaction (SAT) & $\begin{array}{l}0.219 \\
0.048\end{array}$ & $\begin{array}{l}-0.305 \\
0.093\end{array}$ & $\begin{array}{l}0.693 \\
0.480\end{array}$ & $\begin{array}{l}0.529 \\
0.280\end{array}$ & $\begin{array}{l}0.598 \\
0.358\end{array}$ & $\begin{array}{l}0.82 \\
0.66\end{array}$ & \\
\hline 7-eWoM & $\begin{array}{l}0.124 \\
0.015\end{array}$ & $\begin{array}{l}0.135 \\
0.018\end{array}$ & $\begin{array}{l}0.260 \\
0.068\end{array}$ & $\begin{array}{l}0.310 \\
0.096\end{array}$ & $\begin{array}{l}0.282 \\
0.080\end{array}$ & $\begin{array}{l}0.481 \\
0.231\end{array}$ & $\begin{array}{l}0.70 \\
0.61\end{array}$ \\
\hline
\end{tabular}

Figure 3. Final research model

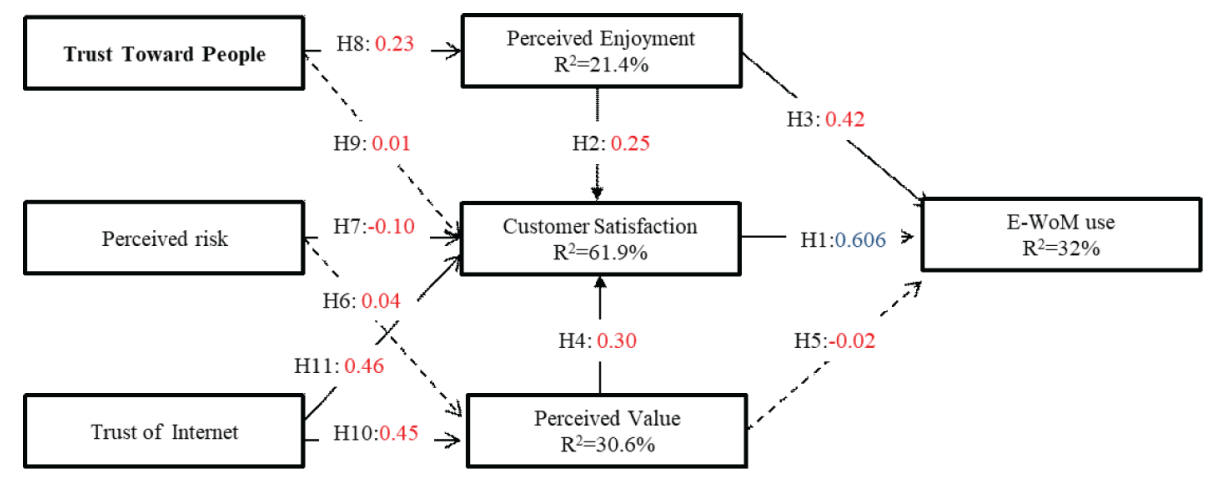

Contribution 1: Differential influences of trust and risk perception on perceived value, perceived enjoyment and satisfaction on eWoM use.

Our proposed comprehensive model of information usefulness extends the existing eWoM and online review literatures. This is the first study that examines the impact of six factors on eWoM creation in s-commerce based Instagram as opposed to prior pre-adoption of s-commerce web sites and Facebook studies (Shin, 2013; Hu et al., 2016; Wang \& Yu, 2017; Mikalef et al., 2017; Farivar et al., 2017; Zhang et al., 2018; Cheng et al., 2019; Molinillo et al., 2020), which have previously focused on antecedents. Accordingly, our findings contribute to extend the findings of previous research related to the eWoM creation. This study also shows the relative importance of these factors on eWoM. Yet, to the best of our knowledge, no work has examined how all these factors influence eWoM-use in s-commerce (see Table 1, and appendix 3). The model predicts variance in eWoM use $\left(\mathrm{R}^{2}=32 \%\right)$ which is similar to previous related eWoM intention studies (Cheung et al., 2009; Mikalef et al., 2017; Mikalef et al., 2013; Qin \& Kong, 2015; Cheng et al., 2019; Molinillo et al., 2020) and even, it was larger than what was found by (Kim \& Park, 2013) $\left(\mathrm{R}^{2}=18.1 \%\right)$ and (Pöyry et al., 2013) $\left(\mathrm{R}^{2}=10 \%\right)$. 
Table 6. Results of Path analysis

\begin{tabular}{|l|l|l|l|l|}
\hline \multicolumn{1}{|c|}{ Path } & Hypotheses & \multicolumn{1}{|c|}{ Betas, $\boldsymbol{\beta s}$} & \multicolumn{1}{c|}{ t-value } & \multicolumn{1}{c|}{$\begin{array}{c}\text { Significant } \\
\text { or Not } \\
\text { Significant }\end{array}$} \\
\hline Satisfaction $\rightarrow$ eWoM Use & H1 & 0.60 & 7.20 & S \\
\hline Perceived Enjoyment $\rightarrow$ Satisfaction & H2 & 0.25 & 12.00 & S \\
\hline Perceived Enjoyment $\rightarrow$ eWoM Use & H3 & 0.42 & 8.01 & S \\
\hline Perceived Value $\rightarrow$ Satisfaction & H4 & 0.30 & 6.20 & S \\
\hline Perceived Value $\rightarrow$ eWoM Use & H5 & -0.02 & 1.70 & NS \\
\hline $\begin{array}{l}{[\text { Perceived enjoyment } \rightarrow \text { e-WoM use] }>} \\
{[\text { Perceived Value } \rightarrow \text { eWoM Use] }}\end{array}$ & H5a & - & - & S \\
\hline Perceived risks $\rightarrow$ Perceived value & H6 & 0.04 & 1.20 & NS \\
\hline Perceived risks $\rightarrow$ Satisfaction & H7 & -0.10 & 11.40 & S \\
\hline Trust toward people $\rightarrow$ Perceived enjoyment & H8 & 0.23 & 14.90 & S \\
\hline Trust toward people $\rightarrow$ Satisfaction & H9 & 0.01 & 0.90 & NS \\
\hline Trust of Internet $\rightarrow$ Perceived value & H10 & 0.45 & 7.80 & S \\
\hline Trust of Internet $\rightarrow$ Satisfaction & H11 & 0.46 & 8.20 & S \\
\hline
\end{tabular}

Contribution 2: Differential effects of antecedents of s-commerce eWoM use in a new Arab context.

Salvatori \& Marcantoni (2015) pointed to the scarcity of research that used models and theories for understanding s-commerce adoption. This research contributed to reducing this gap: (i) Our study is the first study that sheds light on factors that contribute to creating eWoM use in the context of s-commerce in a new Arab context that has received little attention and indeed, misunderstood by western scholars. (ii) Our model does not focus on intention to use only as in the case of the few Arab s-commerce studies (Gibreel et al., 2018; Bugshan \& Attar, 2020; Doha et al., 2019) but on the real use of eWoM for s-commerce. (iii) Our model was also validated using Instagram, a more contemporary OSN tool that was not the focus in previous s-commerce studies (see Appendix 1). (iv) This is achieved by targeting a sample of active Instagram users in Kuwait $(n=843)$ which is larger than any prior s-commerce adoption study.

Contribution 3: Structure the studied factors according to TAM and marketing studies.

Previous s-commerce have studied utilitarian and hedonic value and integrated them in different ways either as intention to use eWoM (Mikalef et al., 2013) or intention to shopping (Shen, 2012; Shin, 2013; Pöyry et al., 2013; Sharma \& Crossler, 2014; Gan \& Wang, 2017; Zhang et al., 2018). However, as mentioned earlier, these studies do not comply with well-known theory models (e.g. TAM) and marketing studies and we succeed in aligning these factors in term of value-satisfactionloyalty (Rouibah et al., 2015).We corrected this and followed Mikalef et al. (2013) study, who used perceived value and perceived enjoyment as mediating factors, and replaced their antecedents by trusting factors (trust of other people and trust of internet/Instagram) and perceived risk, and we added satisfaction between these mediating factors and eWoM current use. Unlike previous studies (Sharma \& Crossler, 2014) who failed the find significant effect of perceived enjoyment on intention to purchase, and others (Shen, 2012; Mikalef et al., 2013; Pöyry et al., 2013; Gan \& Wang, 2017) who found perceived value exerts more effect on intention, our result is the first to reveal that perceived 
value has no direct effect on eWoM use, and perceived enjoyment exerts more effect on eWoM current use than perceived value. This demonstrates the importance of enjoyment and fun as an effective and important driver in s-commerce adoption in the Arab world as previously shown (Rouibah, 2008; Zhang, 2013). This result also corroborates partially with studies that focus on intention to purchase (Zhang et al., 2018; Chen et al., 2017; Shin, 2013). Two potential explanations may be advocated. These two results reflect the uniqueness of the Arab culture or the uniqueness of the Instagram context, which therefore call for caution and more future research to ascertain them.

Contribution 4: Impact of trusting factors and risks on eWoM current use.

While prior studies adopted Mayer's view of perceived trust and included either trust in vendors or individual's trust of s-commerce providers on intention to purchase (Kim \& Park, 2013; Hajli et al., 2017; Akman \& Mishra, 2017; Gibreel et al., 2018; Farivar et al., 2017; Molinillo et al., 2020), our study followed the McKnight et al. (1998) which is the first that combines both individual's disposition to trust (trust of other people), and institution-based trust (trust of internet/ Instagram) on eWoM use and also from the very rare studies (Cheng et al., 2019; Farivar et al., 2017) that focused on intention to purchase instead.

Our results reveal that trust of the internet increases eWoM use through the mediation of customer satisfaction. And, thus eWoM use is largely determined by the path alongside trust of the internet and user satisfaction. The strong effect of trust of internet support prior Arab studies (e.g., Al-Hajri, 2008) who found that among the obstacles hindering technology adoption were the lack of customer's trust in Internet, perceived risk and lack of customer awareness about Internet. Finally, while most existing s-commerce studies ignored perceived risk with its different facets, this is the first study that included it and found that it has no direct effect on perceived value. And this result is surprising as many past studies relating to the modified TAM found perceived risk negatively correlated with perceived value/ perceived benefits (Yang et al., 2015). One potential explanation is that while prior studies(Lim, 2003; Yang et al., 2015) succeeded in showing that perceived risk as a complex construct that includes many sub-constructs i.e., price loss, time loss, quality loss lack of good feel of product, after-sale service loss, and value loss, our study found only three items correlating with perceived risk (lack of good feel of product, price, and value). The low impact of perceived risk on perceived value supports the findings of a previous Kuwaiti study (Rouibah et al., 2016) which suggested that either the inclusion of perceived enjoyment neutralized the effect of perceived risk or the amenability of this finding to the Arab context only, and indeed, this calls for further investigation to validate such conjunctures.

\section{Practical Contributions}

From a managerial perspective, this study shows mechanism to increase s-commerce satisfaction and eWoM use in the context of Instagram tool. Today, with the widespread of eWoM over OSNs, consumers can easily access, search and share reviews related to product information around the globe, and thus, may influence the behavior of numerous consumers either by voicing their own experiences or by deterring their purchase decision. Many researchers working in the field call for new efforts to understand consumer behavior in online communities and, more importantly, how online business may disseminate this knowledge (Akman \& Mishra, 2017; Zhang et al., 2010; Cheung \& Lee, 2012). Therefore, the authors suggest that online companies should encourage customer to post their reviews related experience (satisfaction, perceived value, perceived enjoyment). These companies should, in fact, make a conscious effort to organize and present these reviews under different categories which will play important persuasive role on potential consumers. This is in line with what Amazon.com did with the presentation of product reviews during 2007-2009 (Hu et al., 2016). The firm initially presented reviews according to their urgency, then valence, then importance in Amazon's eyes and finally their helpfulness as rated by review readers. Our study offers and suggests possible new strategies for potential marketing of using Instagram technology to promote s-commerce via eWoM 
based on six factors. Therefore, specifically, online business in Kuwait and Arab countries in general are encouraged to set up an Instagram accounts or to connect sections on their websites to Instagram, holding previous customer testimonials about their products/services supported with some evidence such as video clips or pictures.

\section{Limitations and Future Research}

Like any behavioral study, we report the following limitations and implications for researchers. Firstly, our study focused solely on conducting s-commerce using Instagram. And indeed, expanding this research later to include other s-commerce tools could provide more comprehensive insights. Secondly, the questionnaire was a "snap-shot" instead of longitudinal study and could be followed with more studies in the future. Thirdly, while we used a random sample of Kuwaiti consumers, we also used a sample composed from just one country. It is worth to expand the study to other Arab countries with high Instagram penetration as the case of the GCC countries. Following Alcántara-Pilar et al. (2018) who found that language affect perception of risks, and since the GCC countries include high percentage of expatriates and foreign labor force, therefore, our findings may not hold for other Arab countries in addition to other reasons including the low rates of ICT adoption, and preferences for other OSN tools in different Arab countries. Thus, with the increase of s-commerce (Nakayama \& Wan, 2019) we suggest to pursue a future study in order to test the effect of language (Arab vs. English) on the validation of the proposed model across these countries using a sample that include both Arab and English speakers. Fourthly, our research model succeeded to explain only $32 \%$ in the variance of eWoM use and $61.9 \%$ of satisfaction, which calls for adopting more new variables in any future research. One potential direction is to include the quality of both review and the source. In fact we included eWoM use, and we ignored the effect of whether the recommendation as being perceived to as positive or negative since such perceptions, according to Cheung $\&$ Thadani (2012) depends on the information quality (stimulus) and source credibility (communicator) and can be used to improve the model.

Finally, because consumers and eWoM authors seldom meet, and because of the podcasted rumors that reviews are sometimes biased, consumers are often unsure about the reliability and the truthfulness of eWoM. Therefore, we suggest pursuing future studies to include perceptions of target respondents regarding positive and negative reviews and their effect on their continuous use of s-commerce. There are many reviews posted either on third party web sites dedicated to post customer experiences (e.g. TripAdvisor) or posted directly on web sites of niche market service companies such (e.g. Instagram accounts). According to our experience, perceptions that are more negative are posted on the former than the later. Therefore, an interesting research perspective is to encourage future experimentations about the effect of the two eWoM perceptions available in two different platforms and compare their effect on adoption of s-commerce, by including information quality and source credibility. In studying the effect of these factors, future studies are encouraged as not to focus only on text reviews but also to include pictures and video reviews as their popularity increases (Xu et al., 2015) and video procure more perceived enjoyment. Lastly, since negative eWoM entail risks perceptions, we also encourage to include the nine main dimensions of perceived risk (financial, performance, social, physical, psychological, time loss, personal, privacy, and source) (Luo et al., 2010; Lim, 2003) and trust as multi-construct (competence beliefs, benevolent beliefs, integrity beliefs) with the purpose to test whether the inclusion of these factors lead to current use of s-commerce or not (Lee et al., 2017).

\section{CONCLUSION}

To the best of our knowledge, this study is one of its kinds in this research direction that examined six antecedents (three exogenous and three mediators) of eWoM use in as-commerce context. We examined these factors using a modified TAM model and we aligned it according to the value- 
satisfaction loyalty chain as advocated by marketing and consumer behavior. We find differential impacts of these factors on eWoM use and highlighted different contributions and contentions for both researchers and professionals and highlighted areas for further research in this important area.

\section{ACKNOWLEDGMENT}

This research was funded by Kuwait University, Research Grant IQ 02/16. The author acknowledges the Research Administration Project for its support. 


\section{REFERENCES}

Abed, S. S. (2020). Social commerce adoption using TOE framework: An empirical investigation of Saudi Arabian SMEs. International Journal of Information Management, 53, 102118. doi:10.1016/j.ijinfomgt.2020.102118

Agarwal, R., \& Karahanna, E. (2000). Time flies when you're having fun: Cognitive absorption and beliefs about information technology usage. Management Information Systems Quarterly, 24(4), 665-694. doi:10.2307/3250951

Akman, I., \& Mishra, A. (2017). Factors influencing consumer intention in social commerce adoption. Information Technology \& People, 30(2), 356-370. doi:10.1108/ITP-01-2016-0006

Al-Debei, M. M., Akroush, M. N., \& Ashouri, M. I. (2015). Consumer attitudes towards online shopping: The effects of trust, perceived benefits, and perceived web quality. Internet Research, 25(5), 707-733. doi:10.1108/ IntR-05-2014-0146

Al-Hajri, S. (2008). The adoption of e-Banking: The case of Omani Banks. International Review of Business Research Papers, 4, 120-128.

Aladwani, A. M. (2018). A quality-facilitated socialization model of social commerce decisions. International Journal of Information Management, 40, 1-7. doi:10.1016/j.ijinfomgt.2018.01.006

Alcántara-Pilar, J. M., Del Barrio-García, S., \& Rodríguez-López, M. E. (2018). Does language matter? A cross-national comparison of the moderating effect of language on website information-processing. Journal of Business Research, 88, 66-78. doi:10.1016/j.jbusres.2018.03.011

Baethge, C., Klier, J., \& Klier, M. (2016). Social commerce-State-of-the-art and future research directions. Electronic Markets, 26(3), 269-290. doi:10.1007/s12525-016-0225-2

Beaulac, H. (2020) The Power of Social Shopping on Instagram (and How to Sell More in 2020). Academic Press.

Biernacki, P., \& Waldorf, D. (1981). Snowball sampling: Problems and techniques of chain referral sampling. Sociological Methods \& Research, 10(2), 141-163. doi:10.1177/004912418101000205

Brusso, R. C. (2015). Employee Behavioral Intention and Technology Use: Mediating Processes and Individual Difference Moderators. In Psychology. Old Dominion University.

Bugshan, H., \& Attar, R. W. (2020). Social commerce information sharing and their impact on consumers. Technological Forecasting and Social Change, 153, 119875. doi:10.1016/j.techfore.2019.119875

Chen, W.-K., Chang, D.-S., \& Chen, C.-C. (2017). The role of utilitarian and hedonic values on users' continued usage and purchase intention in a social commerce environment. Journal of Economics and Management, 13, $193-220$.

Cheng, X., Gu, Y., \& Shen, J. (2019). An integrated view of particularized trust in social commerce: An empirical investigation. International Journal of Information Management, 45, 1-12. doi:10.1016/j.ijinfomgt.2018.10.014

Cheung, C. \& Lee, M. K. (2000). Trust in Internet shopping: A proposed model and measurement instrument. AMCIS 2000 Proceedings, 406.

Cheung, C. M., \& Lee, M. K. (2012). What drives consumers to spread electronic word of mouth in online consumer-opinion platforms. Decision Support Systems, 53(1), 218-225. doi:10.1016/j.dss.2012.01.015

Cheung, C. M., \& Thadani, D. R. (2012). The impact of electronic word-of-mouth communication: A literature analysis and integrative model. Decision Support Systems, 54(1), 461-470. doi:10.1016/j.dss.2012.06.008

Cheung, M. Y., Luo, C., Sia, C. L., \& Chen, H. (2009). Credibility of electronic word-of-mouth: Informational and normative determinants of on-line consumer recommendations. International Journal of Electronic Commerce, 13(4), 9-38. doi:10.2753/JEC1086-4415130402

Chu, S.-C., \& Choi, S. M. (2011). Electronic word-of-mouth in social networking sites: A cross-cultural study of the United States and China. Journal of Global Marketing, 24(3), 263-281. doi:10.1080/08911762.2011.592461

Chu, S.-C., \& Sung, Y. (2015). Using a consumer socialization framework to understand electronic word-ofmouth (eWOM) group membership among brand followers on Twitter. Electronic Commerce Research and Applications, 14(4), 251-260. doi:10.1016/j.elerap.2015.04.002 
Coursaris, C. K., Van Osch, W., \& Albini, A. (2018). Antecedents and consequents of information usefulness in user-generated online reviews: A multi-group moderation analysis of review valence. AIS Transactions on Human-Computer Interaction, 10, 1-25. doi:10.17705/1thci.00102

Daft, R. L., \& Lengel, R. H. (1986). Organizational information requirements, media richness and structural design. Management Science, 32(5), 554-571. doi:10.1287/mnsc.32.5.554

Davis, F., Bagozzi, R., \& Warshaw, P. (1989). User acceptance of computer technology: A comparison of two theoretical models. Management Science, 35(8), 982-1003. doi:10.1287/mnsc.35.8.982

Delone, W. H., \& McLean, E. R. (2003). The DeLone and McLean model of information systems success: A tenyear update. Journal of Management Information Systems, 19(4), 9-30. doi:10.1080/07421222.2003.11045748

Doha, A., Elnahla, N., \& McShane, L. (2019). Social commerce as social networking. Journal of Retailing and Consumer Services, 47, 307-321. doi:10.1016/j.jretconser.2018.11.008

Elliott, N. (2015). How Does Your Brand Stack Up On Facebook, Twitter, And Instagram? Academic Press.

Farivar, S., Turel, O., \& Yuan, Y. (2017). A trust-risk perspective on social commerce use: An examination of the biasing role of habit. Internet Research, 27(3), 586-607. doi:10.1108/IntR-06-2016-0175

Fornell, C., \& Larcker, D. F. (1981). Structural equation models with unobservable variables and measurement error: Algebra and statistics. SAGE Publications Sage CA.

Forsythe, S., Liu, C., Shannon, D., \& Gardner, L. C. (2006). Development of a scale to measure the perceived benefits and risks of online shopping. Journal of Interactive Marketing, 20(2), 55-75. doi:10.1002/dir.20061

Gan, C., \& Wang, W. (2017). The influence of perceived value on purchase intention in social commerce context. Internet Research, 27(4), 772-785. doi:10.1108/IntR-06-2016-0164

Gauri, D. K., Bhatnagar, A., \& Rao, H. (2008). Role of word of mouth in online store loyalty. Communications of the ACM, 51(3), 89-91. doi:10.1145/1325555.1325572

Ghandor, F. (2011). How I Did It: The CEO of Aramex on Turning a Failed Sale into a Huge Opportunity. Academic Press.

Gibreel, O., AlOtaibi, D. A., \& Altmann, J. (2018). Social commerce development in emerging markets. Electronic Commerce Research and Applications, 27, 152-162. doi:10.1016/j.elerap.2017.12.008

Global Digital Report. (2020). The Global State of Digital in 2019. Author.

Greenlight. (2020). Digital marketing Agency. Author.

Hair, J. F., Black, W. C., Babin, B. J., Anderson, R. E., \& Tatham, R. L. (1998). Multivariate data analysis. Prentice Hall.

Hajli, N., Lin, X., Featherman, M., \& Wang, Y. (2014). Social word of mouth: How trust develops in the market. International Journal of Market Research, 56(5), 673-689. doi:10.2501/IJMR-2014-045

Hajli, N., Sims, J., Zadeh, A. H., \& Richard, M.-O. (2017). A social commerce investigation of the role of trust in a social networking site on purchase intentions. Journal of Business Research, 71, 133-141. doi:10.1016/j. jbusres.2016.10.004

Han, H., Xu, H., \& Chen, H. (2018). Social commerce: A systematic review and data synthesis. Electronic Commerce Research and Applications, 30, 38-50. doi:10.1016/j.elerap.2018.05.005

Hennig-Thurau, T., Gwinner, K. P., Walsh, G., \& Gremler, D. D. (2004). Electronic word-of-mouth via consumeropinion platforms: What motivates consumers to articulate themselves on the internet? Journal of Interactive Marketing, 18(1), 38-52. doi:10.1002/dir.10073

Hirschman, E. C., \& Holbrook, M. B. (1982). Hedonic consumption: Emerging concepts, methods and propositions. Journal of Marketing, 46(3), 92-101. doi:10.1177/002224298204600314

Holbrook, M. B., \& Hirschman, E. C. (1982). The experiential aspects of consumption: Consumer fantasies, feelings, and fun. The Journal of Consumer Research, 9(2), 132-140. doi:10.1086/208906 
Hong, W., Chan, F. K., Thong, J. Y., Chasalow, L. C., \& Dhillon, G. (2013). A framework and guidelines for context-specific theorizing in information systems research. Information Systems Research, 25(1), 111-136. doi:10.1287/isre.2013.0501

Hu, X., Huang, Q., Zhong, X., Davison, R. M., \& Zhao, D. (2016). The influence of peer characteristics and technical features of a social shopping website on a consumer's purchase intention. International Journal of Information Management, 36(6), 1218-1230. doi:10.1016/j.jinfomgt.2016.08.005

Internet World Stats. (2020). Middle East Internet Users, Population and Facebook Statistics. https://www. internetworldstats.com/stats5.htm.

Kim, S., \& Park, H. (2013). Effects of various characteristics of social commerce (s-commerce) on consumers' trust and trust performance. International Journal of Information Management, 33(2), 318-332. doi:10.1016/j. ijinfomgt.2012.11.006

Lee, J. H., Jung, S. H., \& Park, J. (2017). The role of entropy of review text sentiments on online WOM and movie box office sales. Electronic Commerce Research and Applications, 22, 42-52. doi:10.1016/j.elerap.2017.03.001

Lee, Y.-C. (2014). Impacts of decision-making biases on eWOM retrust and risk-reducing strategies. Computers in Human Behavior, 40, 101-110. doi:10.1016/j.chb.2014.08.002

Li, C.-Y., \& Ku, Y.-C. (2018). The power of a thumbs-up: Will e-commerce switch to social commerce? Information \& Management, 55(3), 340-357. doi:10.1016/j.im.2017.09.001

Lim, N. (2003). Consumers' perceived risk: Sources versus consequences. Electronic Commerce Research and Applications, 2(3), 216-228. doi:10.1016/S1567-4223(03)00025-5

Limayem, M., \& Hirt, S. G. (2003). Force of habit and information systems usage: Theory and initial validation. Journal of the Association for Information Systems, 4(1), 4. doi:10.17705/1jais.00030

Lowry, P. B., Cao, J., \& Everard, A. (2011). Privacy concerns versus desire for interpersonal awareness in driving the use of self-disclosure technologies: The case of instant messaging in two cultures. Journal of Management Information Systems, 27(4), 163-200. doi:10.2753/MIS0742-1222270406

Luo, X., Li, H., Zhang, J., \& Shim, J. P. (2010). Examining multi-dimensional trust and multi-faceted risk in initial acceptance of emerging technologies: An empirical study of mobile banking services. Decision Support Systems, 49(2), 222-234. doi:10.1016/j.dss.2010.02.008

Mayer, R. C., Davis, J. H., \& Schoorman, F. D. (1995). An integrative model of organizational trust. Academy of Management Review, 20(3), 709-734. doi:10.5465/amr.1995.9508080335

McKnight, D. H., Cummings, L. L., \& Chervany, N. L. (1998). Initial trust formation in new organizational relationships. Academy of Management Review, 23(3), 473-490. doi:10.5465/amr.1998.926622

McKnight, D. H., Lankton, N. K., Nicolaou, A., \& Price, J. (2017). Distinguishing the effects of B2B information quality, system quality, and service outcome quality on trust and distrust. The Journal of Strategic Information Systems, 26(2), 118-141. doi:10.1016/j.jsis.2017.01.001

Mikalef, P., Giannakos, M., \& Pateli, A. (2013). Shopping and word-of-mouth intentions on social media. Journal of Theoretical and Applied Electronic Commerce Research, 8(1), 17-34. doi:10.4067/S0718-18762013000100003

Mikalef, P., Giannakos, M. N., \& Pappas, I. O. (2017). Designing social commerce platforms based on consumers' intentions. Behaviour \& Information Technology, 36(12), 1308-1327. doi:10.1080/0144929X.2017.1386713

Molinillo, S., Anaya-Sánchez, R., \& Liébana-Cabanillas, F. (2020). Analyzing the effect of social support and community factors on customer engagement and its impact on loyalty behaviors toward social commerce websites. Computers in Human Behavior, 108, 105980. doi:10.1016/j.chb.2019.04.004

Mortenson, M. J., \& Vidgen, R. (2016). A computational literature review of the technology acceptance model. International Journal of Information Management, 36(6), 1248-1259. doi:10.1016/j.ijinfomgt.2016.07.007

Murray, D., \& Howat, G. (2002). The relationships among service quality, value, satisfaction, and future intentions of customers at an Australian sports and leisure centre. Sport Management Review, 5(1), 25-43. doi:10.1016/ S1441-3523(02)70060-0 
Nakayama, M., \& Wan, Y. (2019). The cultural impact on social commerce: A sentiment analysis on Yelp ethnic restaurant reviews. Information \& Management, 56(2), 271-279. doi:10.1016/j.im.2018.09.004

Napoleoncat. (2020). Instagram users in Kuwait. Author.

Olanrewaju, A., Hossain, M., Whiteside, N., \& Mercieca, P. (2020). Social media and entrepreneurship research: A literature review. International Journal of Information Management, 50, 90-110. doi:10.1016/j. ijinfomgt.2019.05.011

Pöyry, E., Parvinen, P., \& Malmivaara, T. (2013). Can we get from liking to buying? Behavioral differences in hedonic and utilitarian Facebook usage. Electronic Commerce Research and Applications, 12(4), 224-235. doi:10.1016/j.elerap.2013.01.003

Qin, L., \& Kong, S. (2015). Perceived helpfulness, perceived trustworthiness, and their impact upon social commerce users' intention to seek shopping recommendations. Journal of Internet Commerce, 14(4), 492-508. doi:10.1080/15332861.2015.1103634

Rice, R. E., \& Aydin, C. (1991). Attitudes toward new organizational technology: Network proximity as a mechanism for social information processing. Administrative Science Quarterly, 36(2), $219-244$. doi: $10.2307 / 2393354$

Rouibah, K. (2008). Social usage of instant messaging by individuals outside the workplace in Kuwait: A structural equation model. Information Technology \& People, 21(1), 34-68. doi:10.1108/09593840810860324

Rouibah, K., \& Al-Qirim, N. (2017). Factors affecting social ecommerce adoption in an Arab country: Findings from a qualitative study. Issues in Information Systems, 18.

Rouibah, K., \& Hamdy, H. (2009). Factors affecting information communication technologies usage and satisfaction: Perspective from instant messaging in Kuwait. Journal of Global Information Management, 17(2), 1-29. doi:10.4018/jgim.2009040101

Rouibah, K., Lowry, P. B., \& Almutairi, L. (2015). Dimensions of business-to-consumer (B2C) systems success in Kuwait: Testing a modified DeLone and McLean IS success model in an e-commerce context. Journal of Global Information Management, 23(3), 41-71. doi:10.4018/JGIM.2015070103

Rouibah, K., Lowry, P. B., \& Hwang, Y. (2016). The effects of perceived enjoyment and perceived risks on trust formation and intentions to use online payment systems: New perspectives from an Arab country. Electronic Commerce Research and Applications, 19, 33-43. doi:10.1016/j.elerap.2016.07.001

Salancik, G. R., \& Pfeffer, J. (1978). A social information processing approach to job attitudes and task design. Administrative Science Quarterly, 23(2), 224-253. doi:10.2307/2392563 PMID:10307892

Salvatori, L., \& Marcantoni, F. (2015). Social commerce: A literature review. In 2015 Science and Information Conference (SAI). IEEE.

Schaupp, L. C., Carter, L., \& McBride, M. E. (2010). E-file adoption: A study of US taxpayers' intentions. Computers in Human Behavior, 26(4), 636-644. doi:10.1016/j.chb.2009.12.017

Sharma, S. \& Crossler, R. E. (2014). Intention to engage in social commerce: Uses and gratifications approach. Academic Press.

Shen, J. (2012). Social comparison, social presence, and enjoyment in the acceptance of social shopping websites. Journal of Electronic Commerce Research, 13, 198.

Shin, D.-H. (2013). User experience in social commerce: In friends we trust. Behaviour \& Information Technology, 32(1), 52-67. doi:10.1080/0144929X.2012.692167

Statistica. (2020). Market size of the e-commerce industry in the Gulf Cooperation Council countries in 2015 and 2020. Author.

Tao, D. (2009). Intention to use and actual use of electronic information resources: Further exploring technology acceptance model (TAM). AMIA ... Annual Symposium Proceedings - AMIA Symposium. AMIA Symposium, 2009, 629. PMID:20351931 
Teng, S., Wei Khong, K., Wei Goh, W., \& Yee Loong Chong, A. (2014). Examining the antecedents of persuasive eWOM messages in social media. Online Information Review, 38(6), 746-768. doi:10.1108/OIR-04-2014-0089

Venkatesh, V., Brown, S. A., \& Bala, H. (2013). Bridging the qualitative-quantitative divide: Guidelines for conducting mixed methods research in information systems. Management Information Systems Quarterly, 37(1), 21-54. doi:10.25300/MISQ/2013/37.1.02

Wang, Y., \& Yu, C. (2017). Social interaction-based consumer decision-making model in social commerce: The role of word of mouth and observational learning. International Journal of Information Management, 37(3), 179-189. doi:10.1016/j.jinfomgt.2015.11.005

Xu, P., Chen, L., \& Santhanam, R. (2015). Will video be the next generation of e-commerce product reviews? Presentation format and the role of product type. Decision Support Systems, 73, 85-96. doi:10.1016/j. dss.2015.03.001

Yan, Q., Wu, S., Wang, L., Wu, P., Chen, H., \& Wei, G. (2016). E-WOM from e-commerce websites and social media: Which will consumers adopt? Electronic Commerce Research and Applications, 17, 62-73. doi:10.1016/j. elerap.2016.03.004

Yang, Q., Pang, C., Liu, L., Yen, D. C., \& Tarn, J. M. (2015). Exploring consumer perceived risk and trust for online payments: An empirical study in China's younger generation. Computers in Human Behavior, 50, 9-24. doi:10.1016/j.chb.2015.03.058

Yoo, C. W., Sanders, G. L., \& Moon, J. (2013). Exploring the effect of e-WOM participation on e-Loyalty in e-commerce. Decision Support Systems, 55(3), 669-678. doi:10.1016/j.dss.2013.02.001

Zeithaml, V. A. (1988). Consumer perceptions of price, quality, and value: A means-end model and synthesis of evidence. Journal of Marketing, 52(3), 2-22. doi:10.1177/002224298805200302

Zhang, J. Q., Craciun, G., \& Shin, D. (2010). When does electronic word-of-mouth matter? A study of consumer product reviews. Journal of Business Research, 63(12), 1336-1341. doi:10.1016/j.jbusres.2009.12.011

Zhang, K., Xu, H., Zhao, H., \& Yu, Y. (2018). Online reviews and impulse buying behavior: The role of browsing and impulsiveness. Internet Research, 28(3), 522-543. doi:10.1108/IntR-12-2016-0377

Zhang, K. Z., \& Benyoucef, M. (2016). Consumer behavior in social commerce: A literature review. Decision Support Systems, 86, 95-108. doi:10.1016/j.dss.2016.04.001

Zhang, P. (2013). The affective response model: A theoretical framework of affective concepts and their relationships in the ICT context. Management Information Systems Quarterly, 37(1), 247-274. doi:10.25300/ MISQ/2013/37.1.11

Zhou, L., Zhang, P., \& Zimmermann, H. (2013). Social commerce research: An integrated view. Electronic Commerce Research and Applications, 12(2), 61-68. doi:10.1016/j.elerap.2013.02.003 
Kamel Rouibah is a Professor of information systems, College of Business Administration (CBA), Kuwait University. He holds a PhD in Information Systems from Ecole Polytechnique of Grenoble, France. Before joining CBA, he worked at the Faculty of Technology Management at Eindhoven (Netherlands) and Institut National de la Recherche Scientifique (France). His research interests include Design of Information Systems, Management Information Systems, Engineering Data Management, Workflow Management, Information System and Information Technology Acceptance, diffusion, and satisfaction. He has authored/coauthored over 50 research publications in peer-reviewed reputed journals and conference proceedings. He was involved in several European projects. His publications appeared in several leading journals: Journal of Strategic Information System, IT \& People, Journal of Global Information Management, Computers in Human Behavior, Computers in Industry; Information Management \& Computer Security, International Journal of Computer Integrated Manufacturing; Robotics \& Computer Integrated Manufacturing Journal; Journal of Decision System; Journal of Engineering Design, International Journal of Handheld Computing Research, Telematics and Informatics, and International Journal for E-Adoption. He has received the excellence younger researcher award from Kuwait University for the academic year 2001/2002. Dr Rouibah has directed many funded research projects, and has served as the program committee member of various international conferences (Australasian Conference of Information Systems-ACIS, Information System Development-ISD; ACM Symposium on Applied Computing on e-Business Applications; IADIS, etc.) and reviewer for various international journals (IT \& People, Journal of Global Information Management, Industrial Management \& Data System, Journal of Electronic Commerce in Organization, International Journal of e-Adoption, International Journal of Computer Integrated Manufacturing, International Journal of Production Research, The Australasian Journal of Information System, Arab Journal of Administrative Sciences, Journal of Global Information Technology Management, Asian Academy of management Journal, Information Management \& Computer Security, Communication of the IIMA.). Dr Rouibah sits on the Editorial Board of several IS journals: Journal of Global Information Management; Journal of Electronic Commerce in Organizations (JECO); International Journal of e-Adoption; The Australasian Journal of Information System, International Journal of Handheld Computing Research, International Journal of Advanced Pervasive and Ubiquitous Computing (IJAPUC). He is the co-editor of "Emerging markets and e-commerce in developing economies" book. He has taught many information systems courses in France, Netherlands, and Kuwait.

Yujong Hwang is a Professor in the School of Accountancy \& MIS at the DePaul University in Chicago and an International Scholar at the Kyung Hee University in South Korea. He was a Visiting Professor in the Kellogg School of Management at the Northwestern University and received PhD in Business from the University of South Carolina. His research on e-commerce, knowledge management and human-computer interaction was published in over 60 refereed journal articles including Journal of Management Information Systems and European Journal of Information Systems. He is an Associate Editor of European Journal of Information Systems, Behaviour \& Information Technology and Journal of Electronic Commerce Research and served as a Program Co-Chair of AMCIS 2013. 